OPEN ACCESS

Edited by:

Graham Wallace,

University of Birmingham,

United Kingdom

Reviewed by:

Loredana Frasca,

National Institute of Health (ISS), Italy

Cheryl Rockwell,

Michigan State University,

United States

*Correspondence:

Seonghyang Sohn

sohnsh@ajou.ac.kr

Specialty section:

This article was submitted to

Autoimmune and

Autoinflammatory Disorders,

a section of the journal

Frontiers in Immunology

Received: 20 May 2021 Accepted: 13 August 2021 Published: 31 August 2021

Citation:

Islam SMS, Ryu H-M, Sayeed HM,

Byun $\mathrm{H}-\mathrm{O}$, Jung $\mathrm{J}-\mathrm{Y}$, Kim H-A,

Suh C-H and Sohn S (2021)

Eubacterium rectale Attenuates

HSV-1 Induced Systemic Inflammation

in Mice by Inhibiting CD83.

Front. Immunol. 12:712312.

doi: 10.3389/fimmu.2021.712312

\section{Eubacterium rectale Attenuates HSV-1 Induced Systemic Inflammation in Mice by Inhibiting CD83}

\author{
S. M. Shamsul Islam ${ }^{1}$, Hye-Myung Ryu ${ }^{2}$, Hasan M. Sayeed ${ }^{1}$, Hae-Ok Byun ${ }^{2}$, \\ Ju-Yang Jung ${ }^{3}$, Hyoun-Ah Kim ${ }^{3}$, Chang-Hee Suh ${ }^{3,4}$ and Seonghyang Sohn ${ }^{1,2 *}$ \\ ${ }^{1}$ Department of Biomedical Science, Ajou University School of Medicine, Suwon, South Korea, ${ }^{2}$ Department of \\ Microbiology, Ajou University School of Medicine, Suwon, South Korea, ${ }^{3}$ Department of Rheumatology, Ajou University \\ School of Medicine, Suwon, South Korea, ${ }^{4}$ Department of Molecular Science and Technology, Ajou University, \\ Suwon, South Korea
}

The purpose of this study was to determine whether administration of the microorganism Eubacterium rectale (E. rectale) could regulate dendritic cell (DC) activation and systemic inflammation in herpes simplex virus type 1-induced Behçet's disease (BD). E. rectale, butyrate-producing bacteria, was administered to BD mice. Peripheral blood leukocytes (PBL) and lymph node cells were isolated and analyzed by flow cytometry. 16S rRNA metagenomic analysis was performed in the feces of mice to determine the differences in the composition of the microbial population between normal and BD mice. Serum cytokine levels were measured by enzyme-linked immunosorbent assay. The frequency of $\mathrm{DC}$ activation marker CD83 positive cells was significantly increased in $\mathrm{PBL}$ of $\mathrm{BD}$ mice. Frequencies of CD83+ cells were also significantly increased in patients with active BD. 16S rRNA metagenomic analysis revealed different gut microbiota composition between normal and $\mathrm{BD}$ mice. The administration of $E$. rectale to $\mathrm{BD}$ mice reduced the frequency of CD83+ cells and significantly increased the frequency of NK1.1+ cells with the improvement of symptoms. The co-administration of colchicine and E. rectale also significantly reduced the frequency of CD83+ cells. Differences in gut microbiota were observed between normal mice and $\mathrm{BD}$ mice, and the administration of $E$. rectale downregulated the frequency of $\mathrm{CD} 83$, which was associated with $\mathrm{BD}$ deterioration. These data indicate that $E$. rectale could be a new therapeutic adjuvant for BD management.

Keywords: Behçet's disease, Eubacterium rectale, dendritic cells, microbiota, inflammation, CD83

\section{INTRODUCTION}

The exact cause of Behçet's disease (BD) is unknown $(1,2)$. BD is characterized by chronic systemic inflammation accompanied by oral aphthous ulcers, genital ulcers, skin lesions, ocular involvement, arthritis, and gastrointestinal and central nervous system involvement $(1,2)$. Herpes simplex virus (HSV) is considered one of the causative factors of BD pathogenesis, and HSV viral DNA particles have been detected in the ocular fluids (3), peripheral blood (4), saliva (5), and skin lesions (6) of BD 
patients. BD has been reported to be associated with significant gut microbiota changes (6). The gut provides a habitat for microbes, and microbes in the gut microenvironment have been shown to influence many physiological conditions (7). The microbiota has been described as contributing to immune system balance to maintain host homeostasis (8) and understanding the normal gut microbiota has made the therapeutic manipulation of the gut ecosystem a rational and realistic future prospect (9). Alterations in the microbial community can impair immune regulation, which can lead to autoimmune disorders (10). BD is a T-helper cell type 1 (Th1) polarized disease (11) and is a chronic inflammatory disease associated with significant gut microbiome changes (12).

HSV-1 induced BD model mice show clinical symptoms similar to those of BD patients, including genital ulcers, oral ulcers, skin lesions, eye involvement, arthritis, and intestinal involvement (13). Although the pathogenesis of $\mathrm{BD}$ is not completely clear, genetic susceptibility, triggering factors, and immunological abnormalities have been reported to play roles in $\mathrm{BD}$ development (1). BD has also been reported to result from $\mathrm{T}$ cell abnormalities, Th1/Th2 imbalance, Th17 polarization (14), and the involvement of the innate immune system (15-17). Organ-specific autoimmune diseases are mediated by an imbalance of $\mathrm{T}$ cell subsets, and autoreactive $\mathrm{T}$ cells are activated by dendritic cells (DC) (18). Dendritic cells are known as the most potent antigen-presenting cells and are essential for $\mathrm{T}$ cell activation. The activation of $\mathrm{T}$ cells is essential for a successful cellular immune response (19). To activate naive $\mathrm{T}$ cells, T cells require at least two signals from DC. The first signal is antigen specificity, which passes through the $\mathrm{T}$ cell receptor (TCR) through the major histocompatibility complex (MHC), causing $\mathrm{T}$ cells to enter the cell cycle. Upon peptide accumulation, the second signal is activated where DC expand the level of expression of co-stimulatory molecules such as CD40, CD83, CD80, and CD86 for T cell proliferation and cytokine production (19-22). Among the co-stimulatory molecules, CD83 plays an important role in the immune response beyond its function as an activation marker (23). CD83 is a member of the Ig gene superfamily and an important marker for the characterization of mature DCs but can be detected on other immune cells $(24,25)$. The downregulation of CD83 through RNA interference in human DC results in the less potent induction of allogeneic $\mathrm{T}$ cell proliferation and decreases interferon (IFN)- $\boldsymbol{\gamma}$ secretion (21). CD83 inhibition by CD83 siRNA was reported to improve the symptoms of BD mice (26).

The production of butyrate by gut microbiota is usually associated with a healthy intestinal environment. Active BD patients showed decreased butyrate production (27). Eubacterium rectale (E. rectale), which accounts for up to $13 \%$ of the gut microbiota in total feces in the human colon and thus, is one of the most prevalent bacterial species, is a major contributor to the production of butyrate (28). Patients with Crohn's disease $(29,30)$, rheumatoid arthritis (RA) (31), and ulcerative colitis (32) have significantly reduced amounts of $E$. rectale, and these patients have lower butyrate concentrations in their feces than healthy individuals. Butyrate treatment downregulated IL-6 in peripheral blood mononuclear cell cultures of patients with BD (33) and the downregulation of IL-6 was associated with BD symptom improvement in mice (34). Metagenomics studies have shown that the gut microbiota is associated with human diseases (35). Therefore, the future therapeutic potential of the gut microbiota remains to be further demonstrated (36). In $\mathrm{BD}$, impaired microbiota may contribute to the development of symptoms (27). However, there is little evidence that specific microbial regulation is directly related to improving symptoms. In this study, we investigated the microbiota associated with $\mathrm{BD}$ in the HSV-1 induced $\mathrm{BD}$ mouse model and demonstrated that $E$. rectale regulated DC activation, leading to an improvement in BD.

\section{MATERIALS AND METHODS}

\section{Patients}

Patients with $\mathrm{BD}$ were diagnosed according to the International Study Group of Behçet's Disease (37). The BD activity index was calculated as outlined in the BD Current Activity Form 2006 (http:// medhealth.leeds.ac.uk/download/910/behcetsdiseaseactivityform). Disease was evaluated following a consultant-led assessment at the time of sample collection. The patients were defined as having active $\mathrm{BD}(\mathrm{BDA})$ if they presented with two or more of the following disease manifestations: oral aphthous ulcers; genital ulcers; positive pathergy test; skin lesions; ocular, vascular, and neurological involvement; and arthritis. Blood sampling was done at the active stage and the inactive stage (BDI) during follow-up after improvement of the symptoms. The patients were recruited from the Department of Rheumatology at Ajou University Hospital, Republic of Korea. The medical history and the clinical characteristics of all subjects were collected by a review of the medical records and an interview with the subject when the samples were collected. This study was approved by the Institutional Review Board of Ajou University Hospital. All subjects provided signed informed consent (approval number: AJIRB-BMR-SMP-13-398).

\section{Animal Experiment}

Institute of Cancer Research (ICR) mice 4 to 5-weeks-old were infected with HSV type $1\left(1 \times 10^{6} \mathrm{pfu} / \mathrm{mL}, \mathrm{F}\right.$ strain) grown in Vero cells as previously described (13). Virus inoculation was performed twice at 10-day intervals followed by 16 weeks of observation. The mice were bred in temperature- and lightcontrolled conventional rooms $\left(20-22^{\circ} \mathrm{C}, 12 \mathrm{~h}\right.$ light/dark cycle). The mice had free access to food and water. During the experimental period, the animals were closely observed and photographed. The mice were handled in accordance with the protocol approved by the Institutional Animal Care and Use Committee of Ajou University (approval number: AMC2018-0017).

\section{BD Symptomatic Mice Induced by HSV-1}

Virus inoculation was performed using published procedures (13). Briefly, the earlobes of mice were scratched with a needle and inoculated with $20 \mu \mathrm{L}$ of $1 \times 10^{6} \mathrm{pfu} / \mathrm{mL} \mathrm{HSV}-1$ (F strain) that had 
been grown in Vero cells. Virus inoculation was performed twice at 10-day intervals. For virus inoculation, the mice were anesthetized by intraperitoneal injection with 2,2,2-tribromo ethanol (240 mg/kg), inoculated with virus, and followed up for five to sixteen weeks to confirm BD symptoms. Several symptoms were observed in the mice following HSV inoculation. BD symptoms including oral ulcers, genital ulcers, erythema, skin pustules, skin ulcers, arthritis, diarrhea, red-eye, loss of balance, and facial swelling were observed in $10 \%$ of the HSV-inoculated mice. Oral, genital, skin ulcers, and eye symptoms were classified as major symptoms while arthritis, intestinal ulceration, and neurological involvement were considered minor symptoms. Mice with one or more major symptoms and one or more minor symptoms were classified as having BD. Each symptom was assigned a score of one. The sum of the different symptom scores was used to determine the severity of $\mathrm{BD}$ using the $\mathrm{BD}$ current activity form 2006 prepared by the International Society for Behçet's Disease (http://medhealth.leeds.ac.uk/download/910/ behcetsdiseaseactivityform). A loss of symptoms or a reduction in lesion size of more than $20 \%$ was an indicator of BD improvement. HSV-1 inoculated asymptomatic mice were used as BD normal (BDN) mice as previously described (13).

\section{Study Design}

Normal healthy mice were randomly divided into three groups and administered 1. phosphate-buffered saline (PBS); 2. RCM medium; and 3. E. rectale. $\mathrm{BD}$ mice were randomly divided into four groups: 1. PBS-treated $\mathrm{BD}$ mice; 2 . butyrate-treated $\mathrm{BD}$ mice; 3 . E. rectale-treated $\mathrm{BD}$ mice; and 4 . colchicine-treated $\mathrm{BD}$ mice. The butyrate-treated BD mice were randomly divided into two groups: 1. oral administration of butyrate and 2 . intraperitoneal injection of butyrate. The E. rectale-treated $\mathrm{BD}$ mice were randomly grouped. Group 1 was BD mice treated with E. rectale in culture media and Group 2 was freeze-dried $E$. rectale. Colchicine-treated $\mathrm{BD}$ mice were randomized into two different groups: colchicine-treatment and colchicine with $E$. rectale treatment (Figure $\mathbf{1}$ ).

\section{S rRNA Metagenomic Analysis}

To analyze the mouse gut microbiota based on 16S rRNA gene amplicon sequences, fresh feces were collected from normal and $\mathrm{BD}$ symptomatic mice. $16 \mathrm{~S}$ rRNA gene sequencing of the V3 and V4 amplicons was performed using $16 \mathrm{~S}$ rRNA gene PCR primer (forward primer 5' -TCG TCG GCA GCG TCA GAT GTG TAT AAG AGA CAG CCT ACG GGN GGC WGC AG-3', reverse primer 5'-GTC TCG TGG GCT CGG AGA TGT GTA TAA GAG ACA GGA CTA CHV GGG TAT CTA ATC C-3'). The number of operational taxonomic units (OTUs) was determined by clustering the sequence from each sample with $97 \%$ sequence identity as a cutoff using quantitative insights into microbial ecology (QIIME) software (v.1.8.0). Taxonomic abundance was counted with a National Center for Biotechnology Information (NCBI) database using a confidence threshold of 0.8 derived from preprocessed reads for each sample.

\section{Bacteria Culture}

The bacterial strain E. rectale KCTC 5835 was purchased from the Korean Collection for Type Cultures (KCTC). E. rectale was cultured anaerobically for five days at $37^{\circ} \mathrm{C}$ in enriched Clostridium medium (RCM) broth (Sparks Becton, MD) supplemented with $0.2 \mathrm{~g} / \mathrm{L} \mathrm{L-cystine} \mathrm{and} 4 \mathrm{~g} / \mathrm{L} \mathrm{Na}_{2} \mathrm{HPO}_{4}$.

\section{Preparation of Lyophilized E. rectale}

E. rectale was freeze-dried at $-85^{\circ} \mathrm{C}$ for 24 hours using an Ilshin FDS8508 freeze-dryer (Gwacheon-si, Gyeonggi-do, Korea). After freeze-drying, the product was weighed, diluted in RCM, and administered orally to the mice.

\section{Medication Administration}

After the onset of BD symptoms, mice were orally administered with $1.7 \times 10^{8}$ or $1.0 \times 10^{9}$ colony-forming unit (C.F.U) of E. rectale bacteria once a day for 10 consecutive days. As a control group, $\mathrm{BD}$ mice were administered RCM (E. rectale culture media) for the same period. In addition, butyrate was administered orally or intraperitoneally to BD mice for 10 days. Colchicine 2 ug per mouse was orally administered to $\mathrm{BD}$ mice once a day for 10 consecutive days. The combination of colchicine and E. rectale was also administered to $\mathrm{BD}$ mice during the same period.

\section{Flow Cytometric Analysis}

Leukocytes were isolated from peripheral blood (PBL) and stained with anti-mouse CD40, CD83, CD80, and CD86 for 30 min at $4^{\circ} \mathrm{C}$. In addition, cells isolated from peripheral blood and LN were stained with CD4, CD11c, CD8, CD11b, and NK1.1 and analyzed with a FACS Aria III flow cytometer (Becton
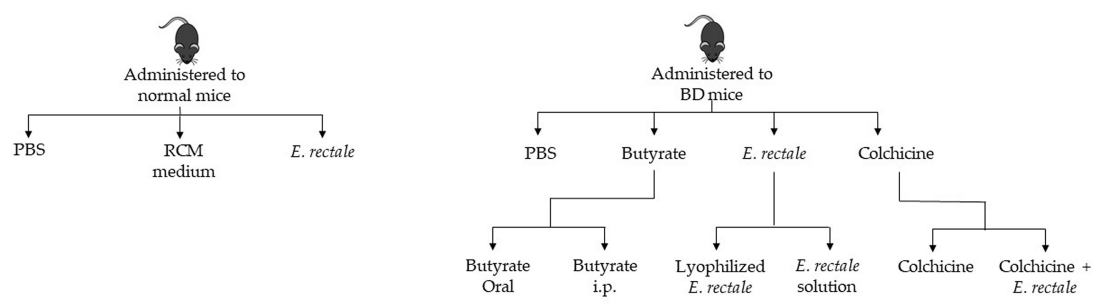

FIGURE 1 | Schematic diagram of the in vivo study. 
TABLE 1 | Clinical characteristics of the Behçet's disease patients.

Patient age sex OU GU Arthritis GI EN Pathergy $\begin{gathered}\text { HLA- } \\ \text { B51 }\end{gathered}$

\section{Active}

$\begin{array}{llllllllll}1 & 42 & \mathrm{M} & - & - & + & - & - & - & - \\ 2 & 41 & \mathrm{~F} & + & - & + & - & + & - & - \\ 3 & 36 & \mathrm{M} & + & - & + & - & - & - & - \\ 4 & 46 & \mathrm{~F} & + & - & + & - & + & - & - \\ 5 & 42 & \mathrm{~F} & - & - & + & - & - & - & - \\ 6 & 49 & \mathrm{~F} & - & - & + & - & - & - & - \\ 7 & 55 & \mathrm{~F} & + & - & + & - & + & - & - \\ 8 & 42 & \mathrm{~F} & - & - & + & - & - & - & - \\ 9 & 26 & \mathrm{~F} & - & - & + & - & - & - & - \\ 10 & 51 & \mathrm{M} & + & - & - & - & - & - & - \\ 11 & 48 & \mathrm{~F} & - & - & - & - & - & - & - \\ 12 & 58 & \mathrm{~F} & + & + & + & + & + & - & - \\ 13 & 50 & \mathrm{~F} & + & + & + & - & - & - & - \\ 14 & 53 & \mathrm{~F} & + & - & + & - & - & - & -\end{array}$

\section{Inactive}

$\begin{array}{llllllllll}1 & 42 & \mathrm{M} & - & - & + & - & - & - & - \\ 2 & 42 & \mathrm{~F} & + & - & + & - & + & - & - \\ 3 & 57 & \mathrm{~F} & - & - & + & - & - & - & - \\ 4 & 36 & \mathrm{~F} & + & + & - & - & - & - & + \\ 5 & 38 & \mathrm{M} & + & - & + & - & - & - & - \\ 6 & 27 & \mathrm{~F} & + & - & + & - & - & - & - \\ 7 & 54 & \mathrm{~F} & - & - & - & - & - & - & -\end{array}$

M, male; F, female; OU, oral ulcers; GU, genital ulcers; Gl, gastrointestinal inflammation; EN, erythema nodosum.

Dickinson, San Jose, CA, USA). Sources of antibodies used in humans and mice are listed in (Supplementary Table ST1).

\section{Regulatory T Cell FACS Staining}

To identify regulatory $\mathrm{T}$ (Treg) cells, isolated PBL were stained with anti-mouse CD4 and anti-mouse CD25. To detect intranuclear Foxp3, an anti-mouse Foxp3 staining kit (eBioscience, San Diego, CA, USA) was used according to the manufacturer's instructions. Briefly, the cells were fixed using Fix/Perm buffer, washed with $1 \mathrm{x}$ permeation buffer, and incubated with anti-Foxp3 antibody. Then, more than 10,000 cells were analyzed by flow cytometry (FACS Aria III, Becton Dickinson, CA, USA).

\section{Measurement of Cytokine IL-17 by Enzyme-Linked-Immunosorbent Assay (ELISA)}

IL-17 levels were analyzed in mouse plasma using a commercial ELISA kit (R\&D Systems, Minneapolis, MN, USA) according to the manufacturer's instructions. The absorbance values of the samples were read at a wavelength of $450 \mathrm{~nm}$ using a Bio-Rad model 170-6850 microplate reader (Hercules, CA, USA). ELISA was repeated in duplicate wells.

\section{Statistical Analysis}

Statistical differences between the experimental groups were determined using Graphpad Prism for Windows (version 8.3.1) (GraphPad Software, La Jolla, CA, USA). The statistical significance of the data was determined by applying the Kruskal-
Wallis test and the Mann-Whitney $\mathrm{U}$ test. The data are expressed as the mean $\pm \mathrm{SD}$ and statistical significance was considered when the p-value was less than 0.05 .

\section{RESULTS \\ Clinical Characteristics of the Patients}

The clinical characteristics of the patients with $\mathrm{BD}$ are summarized in Table 1. Blood sampling was performed twice (active stage and the inactive stage of the disease). The second sampling was performed after symptom improvement. In active BD patients, oral ulcers were found in 8 patients $(57.12 \%)$, genital ulcers in 2 patients (14.28\%), arthritis in 12 patients (85.68\%), gastrointestinal inflammation in 1 patient $(7.14 \%)$, and nodular erythema in 4 patients (25.6\%). Medication is shown in Table 2. Colchicine in 11 (78.6\%), glucocorticoid in $9(64.3 \%)$, azathioprine in 1 (7.14\%), hydroxychloroquine in $3(21.4 \%)$, sulfasalazine in 5 (35.7\%), nonsteroidal anti-inflammatory drugs were administered to 9 patients $(64.3 \%)$ of active BD patients.

\section{Frequency of CD83-Expressing Cells in Healthy Control, Active BD, and Inactive BD Patients}

The frequency of DC-activating co-stimulatory molecule CD83 in active BD patients $(n=14)$, inactive BD patients $(n=7)$, and healthy controls $(n=6)$ was determined by FACS analysis. The frequency of CD83+ cells were significantly increased in the lymphocytes $(33.03 \pm 5.67 \%$ vs. $19.75 \pm 5.02 \%, \mathrm{p}=0.01)$ from BDA patients compared with the HC (Figures 2A). No significant difference was found in the frequency of CD83+ granulocyte, monocyte, and whole cell populations (Figures 2B-D). A representative histogram of CD83+ cells from the $\mathrm{HC}, \mathrm{BDA}$, and BDI groups is shown in Figure 2E.

\section{Frequency of CD83, CD86, CD40, and CD80-Expressing Cells in Normal Control, BD Normal (BDN), and BD Mice}

The frequency of DC expressing co-stimulatory molecules CD83, CD86, CD40, and CD80 in the PBL of mice were analyzed by FACS. The frequency of CD83+ cells in HSV-1 induced BD mice was significantly elevated compared to those in the BDN mice $(40.72 \pm 8.91 \%$ vs. $23.31 \pm 8.51 \%, p=0.05)$ (Figure 3A). The frequency of CD86+ cells was decreased in BD mice compared to $\mathrm{BDN}$ mice $(7.28 \pm 2.18 \%$ vs. $12.45 \pm 4.62 \%)$ but was not statistically significant (Figure 3B). There was no statistically significant difference in the frequency of CD40+ and CD80+ expressing cells between groups (Figures 3C, D). Figure 3E shows representative histograms of CD83+, CD86+, CD40+, $\mathrm{CD} 80+$ cells in control, BDN, and BD mice.

\section{Altered Gut Microbial Composition in HSV-1-Induced BD Symptomatic Mice}

To investigate the composition and function of the gut microbiome in BD mice, 16S rRNA metagenomic analysis was performed in fecal samples from normal mice and BD mice. 
TABLE 2 | Therapeutic history of Behçet's disease patients.

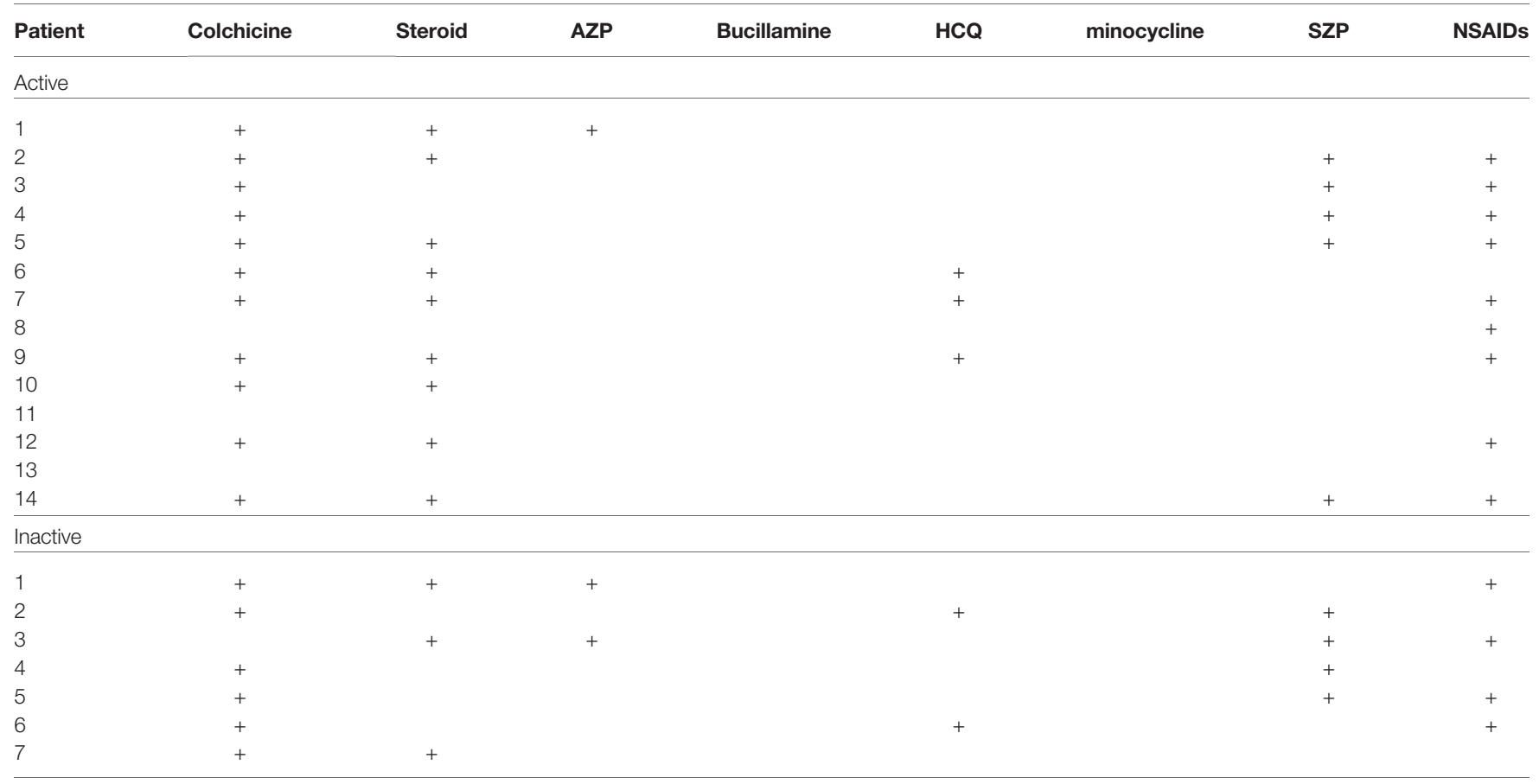

AZP, azathioprine; HCQ, Hydroxychloroquine; SZP, Sulfasalazine; NSAIDs, Nonsteroidal anti-inflammatory drugs.
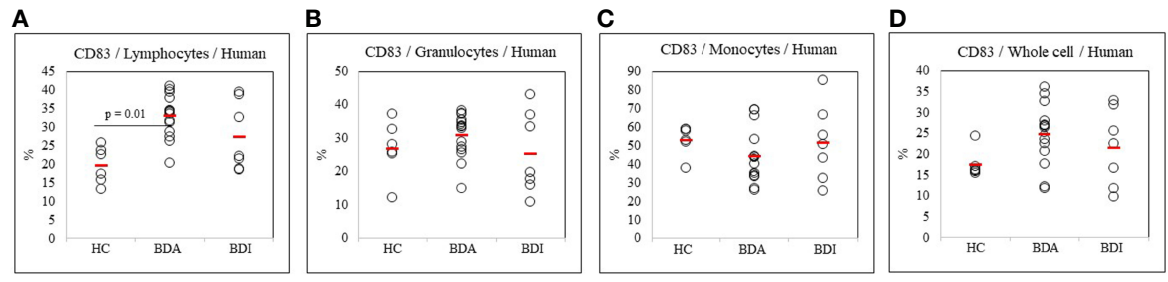

E

CD83

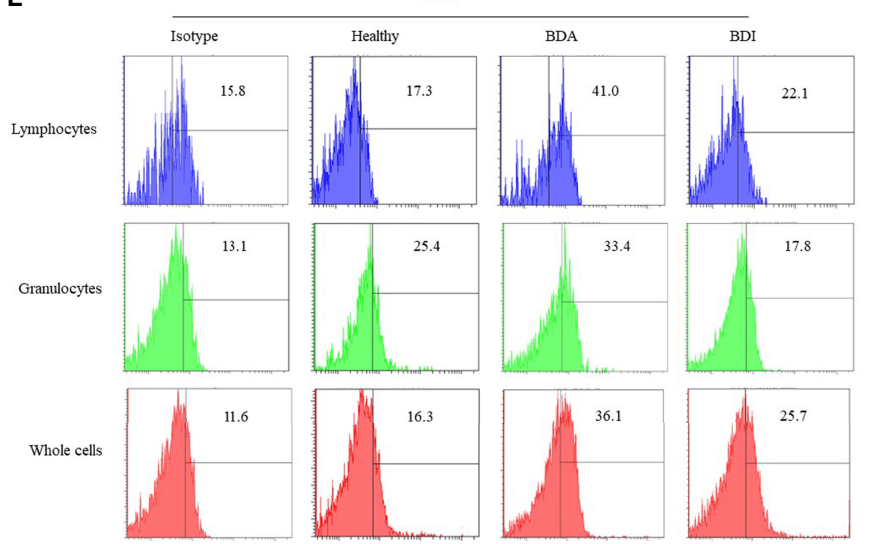

FIGURE 2 | Frequency of CD83+ cells in peripheral blood leukocytes (PBL), lymphocytes, granulocytes, monocytes, and whole cells (A-D) of healthy controls (HC), patients with active Behçet's disease (BDA), and patients with inactive Behçet's disease (BDI). The isolated peripheral blood leukocytes (PBL) were subjected to surface staining and analyzed by flow cytometry. The results were obtained from six HC, fourteen BDA patients, and seven BDI patients. Statistical analysis was performed by the Kruskal-Wallis test. Representative FACS histograms of peripheral blood lymphocytes, granulocytes, and whole cells are shown in (E). 
A

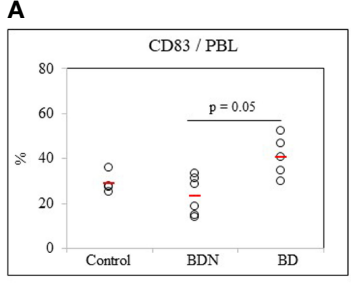

C

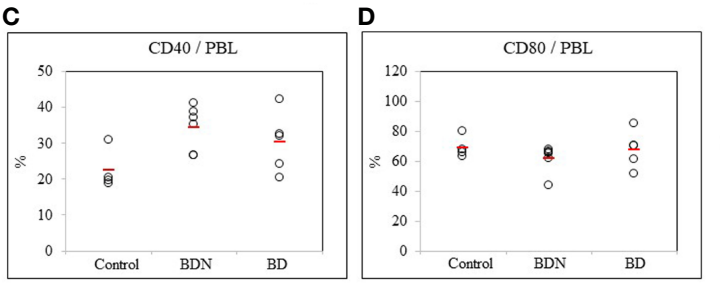

E

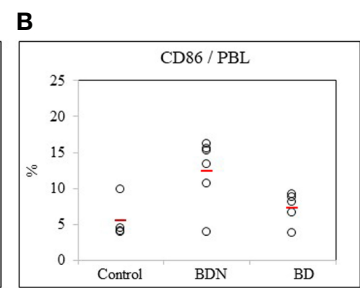

D
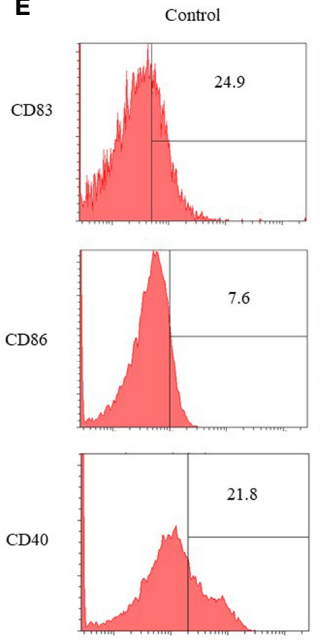

CD80
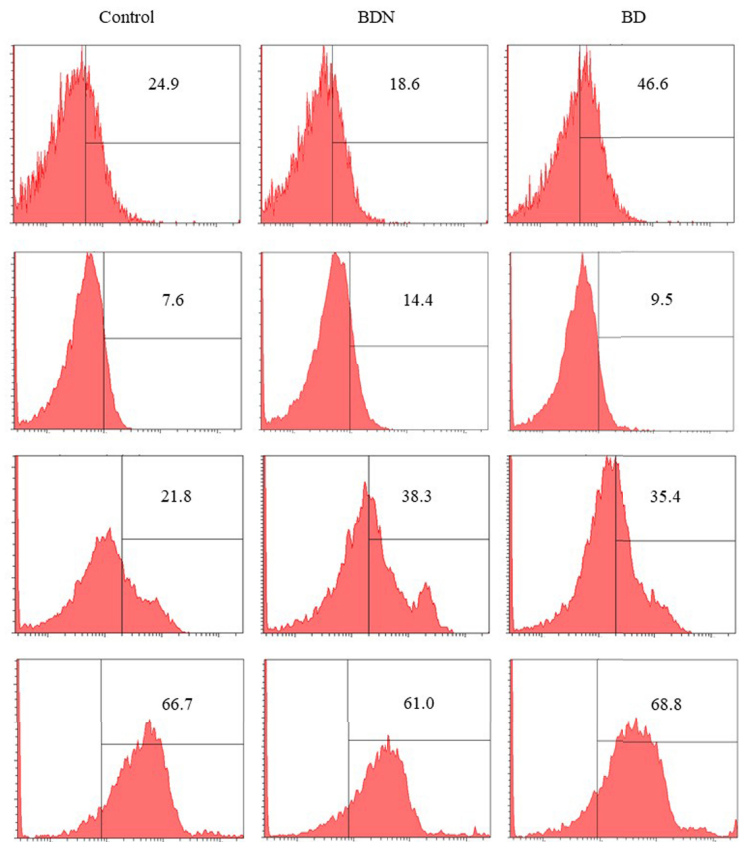

FIGURE 3 | The frequency of DC costimulatory molecules CD83, CD86, CD40, and CD80 (A-D) in whole PBL was assessed in normal, BDN, and BD mice. Isolated PBL were surface stained and evaluated by flow cytometry. A representative histogram of CD83+ cells is shown in (E). For statistical analysis, the KruskalWallis test was performed using GraphPad. The number of mice used in the experimental groups was five in the normal, six in the BDN, and five in the BD group. The experiments were performed independently at least three times.

Based on a National Center for Biotechnology Information (NCBI) classifier comparison of the microbial community, the taxonomic construct distances between the normal and BD mice were determined using the Shannon diversity index and beta diversity and visualized by a principal coordinate analysis (PCoA) plot (Figures 4A-C). According to the fecal sample microbiome analysis, the number of OTUs $(p=0.008)$ and alpha diversity (Shannon index, $\mathrm{p}=0.00003$ ) were significantly increased in $\mathrm{BD}$ mice compared to the normal mice, indicating that the $\mathrm{BD}$ mice had lower microbial diversity (Figures 4A, B). Figure 4D shows the abundance of bacterial flora and Figure 4E is the heat map of the bacterial flora. The results showed that Bacteroidetes, Firmicutes, and Proteobacteria were the dominant phyla in both the normal and BD mice (Figures 4F-H). Phylum Tenericutes ( $\mathrm{p}=0.02$ ) was significantly higher in $\mathrm{BD}$ mice than in normal mice (Figure 4I). The expression of Deferribacteres and Verrucomicrobia was lower in BD mice than in normal mice, but Actinobacteria did not differ between the two groups, and the unassigned bacterial phylum was higher in BD mice (Figures 4J-M). Supplementary Table ST2 shows the differences in fecal microbiota between the normal and $\mathrm{BD}$ mice and the $p$-values.

Among the microbial families, Bacteroidaceae $(\mathrm{p}=0.002)$, Eggerthellaceae $(\mathrm{p}=0.01)$, and Peptococcaceae $(\mathrm{p}=0.0009)$ were significantly lower in BD mice than in normal mice (Figure $4 \mathbf{N}$ and Supplementary Table ST2). Prevotellaceae ( $\mathrm{p}=0.003)$ and Rikenellaceae ( $\mathrm{p}=0.002$ ) were significantly higher in $\mathrm{BD}$ mice than in normal mice. However, the most dominant microbial families Lachnospiraceae, Lactobacillaceae, and Porphyromonadaceae were not significantly different between the groups. At the genus level, Anaerotruncus ( $\mathrm{p}=0.005)$, Bacteroides $(\mathrm{p}=0.002)$, Butyricicoccus $(\mathrm{p}=0.008)$, Coprobacillus ( $\mathrm{p}=0.02)$, Mucispirillum $(\mathrm{p}=0.02)$, Peptococcus $(\mathrm{p}=0.008)$, and Staphylococcus $(\mathrm{p}=0.02)$ were significantly lower in BD mice than in normal mice (Figure 40, Supplementary Table ST2). In contrast, Acetatifactor ( $\mathrm{p}=$ $0.05)$, Alistipes $(p=0.004)$, Desulfovibrio $(p=0.01)$, Helicobacter $(\mathrm{p}=0.04)$, Odoribacter $(\mathrm{p}=0.007)$, Prevotella $(\mathrm{p}=0.006)$, and Vampirovibrio $(\mathrm{p}=0.006)$ were significantly higher in $\mathrm{BD}$ mice than in normal mice (Figure 40 and

\section{Supplementary Table ST2).}

In the bacterial species, Clostridium lavalense $(p=0.03)$, Eubacterium sulci $(\mathrm{p}=0.002)$, Anaerotruncus colihominis $(\mathrm{p}=$ $0.02)$, Asaccharobacter celatus $(\mathrm{p}=0.01)$, Bacteroides caccae $(\mathrm{p}=$ $0.003)$, Bacteroides vulgatus $(p=0.005)$, Eubacterium xylanophilum $(\mathrm{p}=0.02)$, Parabacteroides goldsteinii $(\mathrm{p}=$ $0.01)$, Peptococcus niger $(\mathrm{p}=0.008)$, Roseburia intestinalis $(\mathrm{p}=0.005)$, and Staphylococcus cohnii $(\mathrm{p}=0.03)$ were significantly lower in the $\mathrm{BD}$ mice compared to the normal mice (Figure 4P and Supplementary Table ST2), whereas Clostridium scindens $(\mathrm{p}=0.03)$, Acetatifactor muris $(\mathrm{p}=$ $0.05)$, Alistipes putredinis $(\mathrm{p}=0.01)$, Alistipes senegalensis $(\mathrm{p}=0.05)$, Anaeroplasma bactoclasticum $(\mathrm{p}=0.03)$, Bacteroides acidifaciens $(\mathrm{p}=0.04)$, Helicobacter ganmani $(\mathrm{p}=0.08)$, Helicobacter marmotae $(\mathrm{p}=0.03)$, Odoribacter laneus $(\mathrm{p}=0.01)$, 

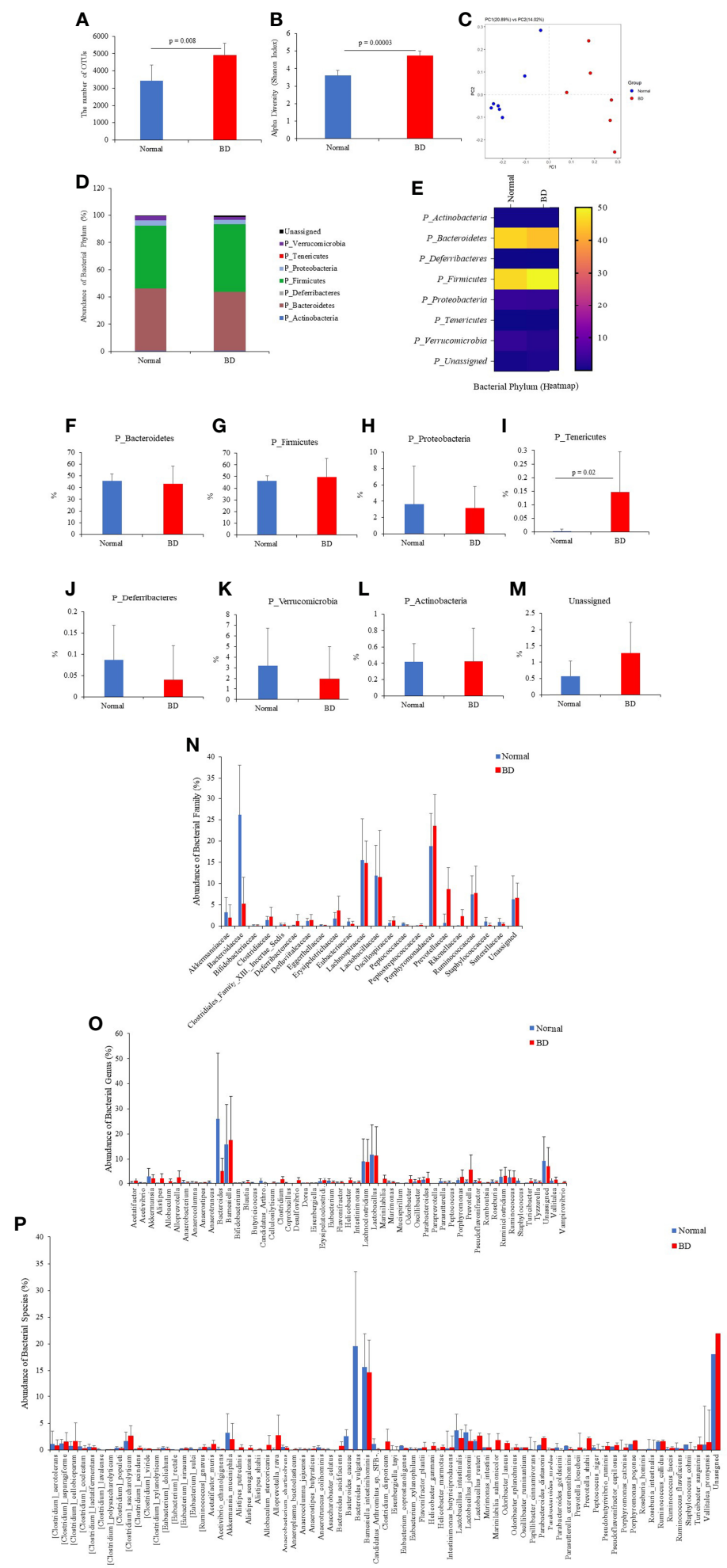

FIGURE 4 | Fresh fecal samples were collected from normal $(n=7)$ and BD mice $(n=6)$, and metagenomic analysis was performed. Sequencing data from 165 rRNA V3 and V4 amplicons were used to perform microbiome analysis. BD mice 16S rRNA amplicon metagenomic analysis revealed an altered gut microbiome composition compared to normal mice. It showed the operational taxonomic units (OTUs) (A), alpha diversity by the Shannon index (B), and beta diversity by principal coordinate analysis (PCoA) (C). The number of phyla (D-M), families (N), genera (O), and species (P) showed significant differences in fecal 165 rRNA sequencing between the normal and BD mice. The $\mathrm{p}$-value was determined by the Mann-Whitney $U$ test. 
Odoribacter splanchnicus $(\mathrm{p}=0.005)$, Parabacteroides merdae $(\mathrm{p}=0.04)$, Prevotella loescheii $(\mathrm{p}=0.01)$, and Porphyromonas catoniae $(\mathrm{p}=0.01)$ were significantly higher in the BD mice than the normal mice (Figure 4P and Supplementary Table ST2).

\section{Butyrate Treatment Increases the Frequency of CD86+ Cells and Improves Symptoms in BD Mice}

Butyrate was administered intraperitoneally and orally to BD mice. The frequency of DCs expressing co-stimulatory molecules CD83, CD86, CD40, and CD80 in the PBL of butyrate-treated $\mathrm{BD}$ mice was measured by FACS analysis. The frequency of CD83+ cells was downregulated in butyrate intraperitoneallytreated $\mathrm{BD}$ mice compared to untreated BD mice $(23.83 \pm 9.32 \%$ vs. $40.72 \pm 8.91 \%)$ but the difference was not statistically significant (Figure 5A). CD86+ cells were significantly increased in $\mathrm{BD}$ mice administered butyrate intraperitoneally $(14.97 \pm 1.76 \%$ vs. $7.28 \pm 2.18 \%, p=0.05)$ and orally $(17.04 \pm$
$10.24 \%$ vs. $7.28 \pm 2.18 \%, p=0.05)$ compared to untreated $\mathrm{BD}$ mice (Figure 5B). No statistical difference was observed in the frequency of CD40+ cells and CD80+ cells after butyrate treatment (Figures 5C, D). Butyrate treatment of BD mice showed improvement in symptoms (Figure 5E).

\section{Butyrate Treatment Increases Regulatory T Cells in BD Mice}

Butyrate was administrated intraperitoneally and orally to BD mice to determine whether butyrate could modulate Treg cells. Treg cell markers CD4, CD25, and Foxp3 were analyzed in PBL by FACS analysis. Intraperitoneal injection or oral administration of butyrate to $\mathrm{BD}$ mice couldn't make any significant difference in the frequency of CD4+ cells (Figure 5F), but intraperitoneal injection of butyrate to BD mice increased the frequency of CD25+ cells (5.07 $\pm 1.40 \%$ vs. $1.08 \pm 0.34 \%)$ and Foxp3+ cells $(6.07 \pm 1.56 \%$ vs. $2.32 \pm$ $0.92 \%$ ) compared to untreated BD mice (Figures 5G, H) but the results were not significantly different. Intraperitoneal injection of butyrate to $\mathrm{BD}$ mice also increased the frequency of $\mathrm{CD} 4+\mathrm{CD} 25+$
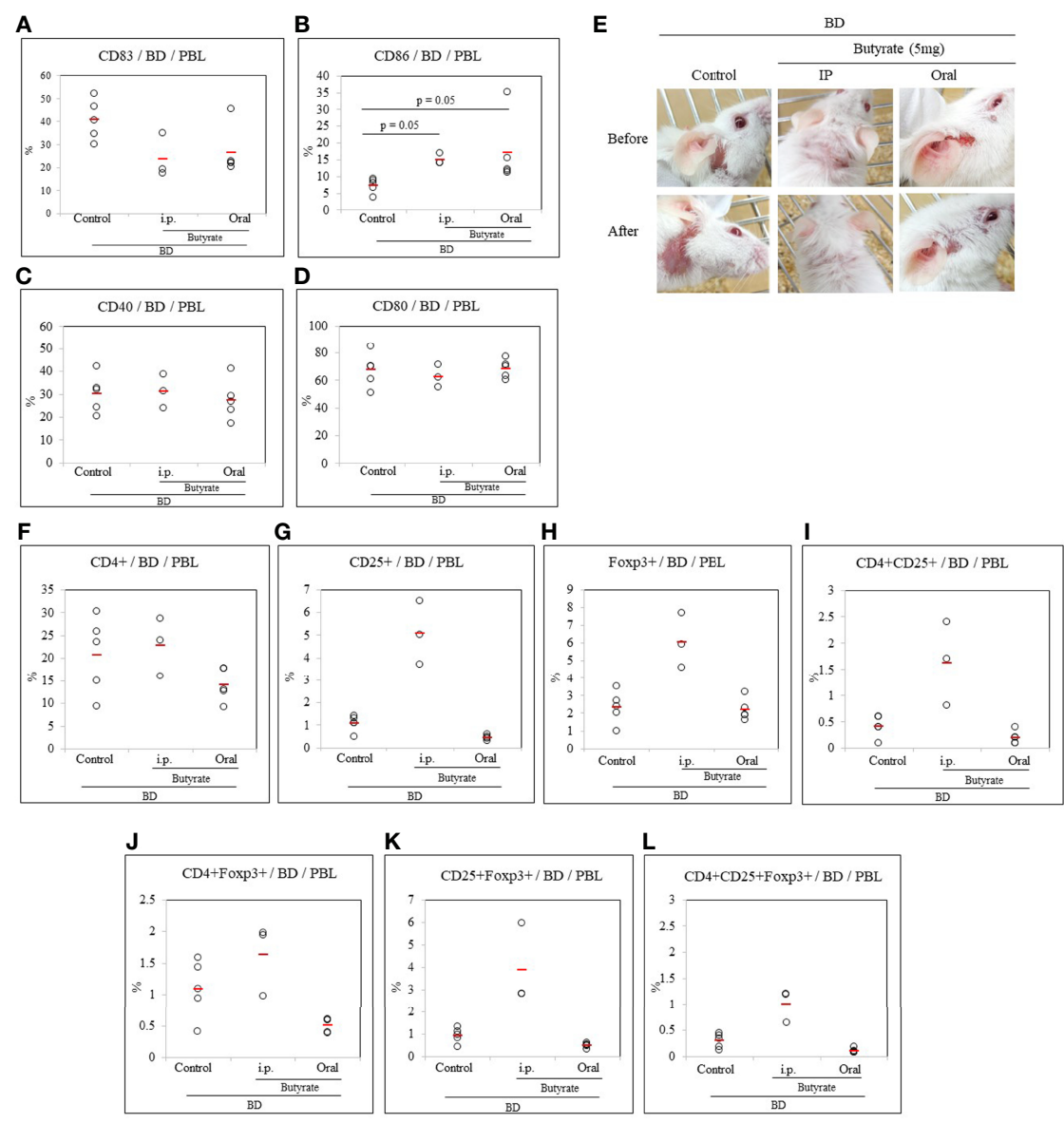

FIGURE 5 | Butyrate affected the frequency of CD83+ cells in BD mice. In BD mice treated with butyrate, the frequency of DC co-stimulatory molecules CD83, CD86, CD40, and CD80 was evaluated by flow cytometric analysis of PBL surface staining (A-D). The intraperitoneal or oral administration of butyrate to BD mice decreased the frequency of CD83+ cells (B) and significantly increased the frequency of CD86+ cells (D). Butyrate treatment improved the symptoms in BD mice (E). The frequency of regulatory T cells was analyzed by FACS after the intraperitoneal or oral administration of butyrate to BD mice (F-L). The p-value was determined by the Kruskal-Wallis test. The experiments were performed independently at least three times. 
cells $(1.63 \pm 0.80 \%$ vs. $0.42 \pm 0.20 \%$ ) (Figure $5 \mathbf{I}$ ), however no differences was observed in CD4+Foxp3+ cells (Figure 5J) among the groups. Intraperitoneal injection of butyrate to $\mathrm{BD}$ mice also increased the frequency of CD25+Foxp3+ cells $(1.63 \pm 0.57 \%$ vs. $1.09 \pm 0.45 \%)$, and CD4+CD25+Foxp3+ cells ( $1.01 \pm 0.32 \%$ vs. $0.29 \pm$ $0.13 \%$ ) compared to untreated $\mathrm{BD}$ mice (Figures $\mathbf{5 K}, \mathbf{L}$ ) but no statistically significant differences were observed. No difference was observed in the frequency of CD4+, CD8+, CD11b+, and CD11c+ cells in the LN cells of BD mice treated intraperitoneally or orally with butyrate (Supplementary Figure S1).

\section{Dose Dependence of Eubacterium rectale on Dendritic Cell Activation Marker Expression in Normal and BD Mice}

Probiotics must be administered in adequate amounts to achieve the benefits. As a result of intraperitoneal and oral administrations of butyrate, Treg expression was different. Therefore, a dosedependence on direct bacterial administration was required. The dose-response effect was tested to determine the appropriate amount of E. rectale to administer to $\mathrm{BD}$ mice. After oral administration of $E$. rectale to normal mice, the frequency of dendritic cell activation marker-positive cells was analyzed by FACS. The dendritic cell activation markers used were CD40, CD83, CD80, and CD86. Three doses of E. rectale $\left(1.7 \times 10^{7}\right.$, $1.7 \times 10^{8}$ and $1.0 \times 10^{9}$ C.F.U/mouse) were administered orally to normal mice for 10 consecutive days once a day. E. rectale treatment at $1.0 \times 10^{9}$ C.F.U significantly reduced the frequency of CD83+ cells compared to the controls $(9.00 \pm 1.29 \%$ vs. $23.97 \pm$ $6.38 \%, p=0.01$ ) (Figure 6A). No significant difference was observed in $\mathrm{CD} 86+$ cell frequency after E. rectale treatment (Figure 6B). The frequency of $\mathrm{CD} 40+$ cells were also significantly downregulated in the $1.0 \times 10^{9}$ C.F.U of E. rectaletreated group compared to the controls $(13.65 \pm 3.89 \%$ vs. $24.95 \pm$ $4.73 \%, \mathrm{p}=0.05$ ) (Figures 6C). No significant difference was observed in $\mathrm{CD} 80+$ cell frequency after E. rectale treatment (Figure 6D). Treatment of $\mathrm{BD}$ mice with $1.0 \times 10^{9}$ C.F.U of $E$. rectale per mouse significantly reduced the frequency of $\mathrm{CD} 83+$ cells compared to untreated BD mice $(20.20 \pm 5.14 \%$ vs. $40.72 \pm$ $8.91 \%, p=0.05$ ) (Figure 6E). The frequency of CD86+ cells and $\mathrm{CD} 40+$ cells was also reduced in E. rectale $\left(1.0 \times 10^{9}\right.$ C.F.U/mice)treated $\mathrm{BD}$ mice compared to $\mathrm{BDN}$ mice $(4.60 \pm 2.0 \%$ vs. $12.45 \pm$ $4.62 \%, p=0.05 ; 19.16 \pm 3.88 \%$ vs. $34.27 \pm 6.20 \%, p=0.05$, respectively) (Figure 6F, G). No significant difference was found in CD80+ cell frequency (Figure $\mathbf{6 H}$ ). A representative histogram of $\mathrm{CD} 83+$ cell frequency in E. rectale-treated $\mathrm{BD}$ mice is shown in Figure 6I.

\section{Eubacterium rectale Treatment Modulates Regulatory T Cells in BD Mice}

CD4+CD25+Foxp3+ Treg cells were analyzed by FACS in E. rectale-treated $\mathrm{BD}$ mice. The frequencies of $\mathrm{CD} 4+$ and $\mathrm{CD} 25+$ cells in $E$. rectale-treated $\mathrm{BD}$ mice were not significant among the groups (Figures 6J, K). The frequency of Foxp3+ cells and $\mathrm{CD} 4+\mathrm{CD} 25+$ cells was increased after E. rectale $\left(1.7 \times 10^{8}\right.$ C.F.U/mouse) treatment compared to untreated BD mice $(9.36 \pm 7.94 \%$ vs. $3.12 \pm 1.75 ; 2.0 \pm 1.36 \%$ vs. $0.78 \pm 0.40$, respectively) (Figures 6L, M). The CD4+Foxp3+ cell frequency was also increased after $E$. rectale $\left(1.0 \times 10^{9}\right.$ C.F.U/mouse) treatment compared to untreated $\mathrm{BD}$ mice $(2.07 \pm 1.30 \%$ vs. $0.75 \pm 0.46$ ), (Figure $6 \mathbf{N}$ ), but the frequencies of CD25+Foxp3+ cells in E. rectale-treated $\mathrm{BD}$ mice were not significant among the groups (Figure 60). The frequencies of CD4+CD25+Foxp3+ regulatory $\mathrm{T}$ cell was upregulated after E. rectale $\left(1.7 \times 10^{8}\right.$ C.F.U/ mouse) treatment, but the difference was not statistically significant $(1.40 \pm 1.21 \%$ vs. $0.25 \pm 0.22)$ (Figure 6P).

\section{Eubacterium rectale Treatment Upregulates NK Cells in BD Mice}

The frequency of NK1.1+ cells in BD mice was lower than in normal mice $(8.30 \pm 2.36 \%$ vs. $15.34 \pm 5.40 \%)$ but the difference was not statistically significant. BD mice administered E. rectale upregulated NK1.1+ cells compared to non-administered BD mice $(19.52 \pm 11.79 \%$ vs. $8.30 \pm 2.36 \%, \mathrm{p}=0.01)$ (Figure 6Q). The frequency of CD4+ cells and CD8+ T cells in the PBL of BD mice was lower than in normal mice $(11.82 \pm 8.54 \%$ vs. $34.78 \pm$ $7.25 \% ; 7.42 \pm 3.06 \%$ vs. $13.10 \pm 3.19 \%$, respectively) (Figures 6R, S). In contrast, the frequency of CD11b+ cells were higher in $\mathrm{BD}$ mice than in normal mice $(59.52 \pm 21.37 \%$ vs. $26.82 \pm 6.12 \%$ ) (Figure 6T) but no statistically significant difference was observed between the groups.

\section{Eubacterium rectale Treatment Reduces Disease Severity Scores and Improves Symptoms in BD Mice}

To determine whether $E$. rectale was able to manage $\mathrm{BD}$ symptoms, E. rectale was orally administered to $\mathrm{BD}$ mice for 10 consecutive days, and symptoms were tracked during that period. $\mathrm{BD}$ mice treated with $E$. rectale culture media were used as controls and maintained for the same period. The severity score of E. rectale-treated $\mathrm{BD}$ mice decreased significantly after 10 days of treatment compared to that of the control-treated BD mice $(1.34 \pm 0.54 \%$ vs. $3.25 \pm 0.5 \%, p=0.02)$ (Figure 6U). Figure $6 \mathrm{~V}$ shows the changes in $\mathrm{BD}$ symptoms 10 days after the administration of $E$. rectale.

\section{Co-Administration of Colchicine and Eubacterium rectale Downregulates CD83 in BD Mice}

Colchicine is a drug frequently used to treat patients with $\mathrm{BD}$ and has been reported to significantly reduce the symptoms $(38,39)$. Colchicine administration to $\mathrm{BD}$ mice reduced the frequency of CD83+ cells compared to untreated BD mice $(25.28 \pm 3.55 \%$ vs $40.72 \pm 8.91 \%$ ) (Figure 7A) but the difference was not statistically significant. The combined administration of colchicine and E. rectale to $\mathrm{BD}$ mice significantly reduced the frequency of CD83+ cells compared to untreated BD mice $(18.67 \pm 3.59 \%$ vs. $40.72 \pm 8.91 \%, p=0.01$ ) (Figure 7A). The administration of colchicine alone or in combination with E. rectale did not show statistically significant differences in the frequency of CD86+, CD40+, and CD80+ cells between the groups (Figures 7B-D). Colchicine alone or in combination with E. rectale improved $\mathrm{BD}$ symptoms in mice (Figure 7E). After the administration of 

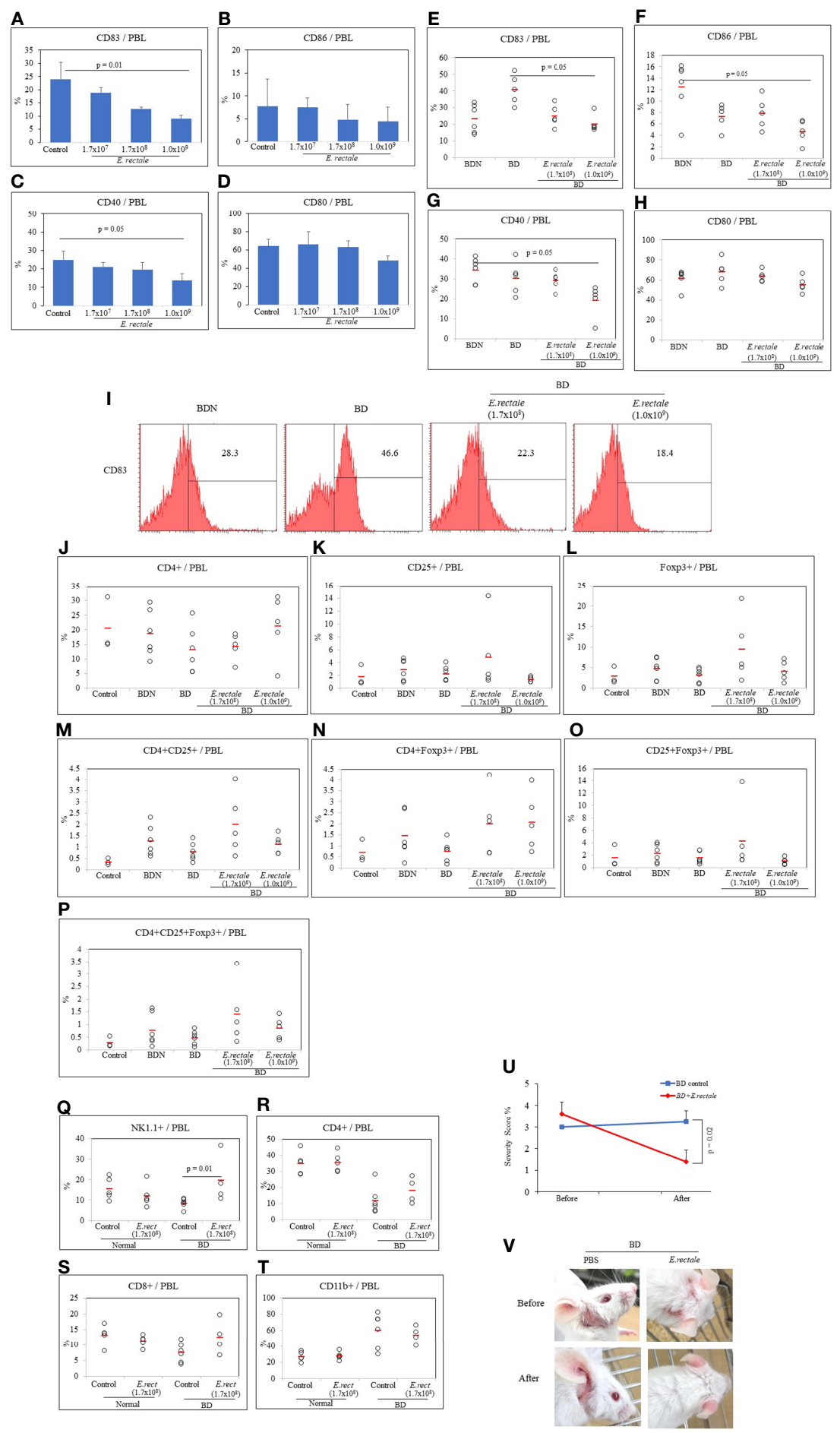

FIGURE 6 | Eubacterium rectale administration regulated dendritic cell activation and regulatory T cells in normal mice. The frequencies of CD83, CD86, CD40 and CD80 on the PBL surface of normal mice treated with E. rectale (1.7x107, 1.7×108, 1.0x109 CFU) for 10 consecutive days were evaluated by flow cytometry (A-D). The frequencies of CD83, CD86, CD40 and CD80 on the surface of the PBL of BD mice treated with E. rectale (1.7x108 and 1.0x109 C.F.U) were assessed by flow cytometry (E-H). Representative histograms of the frequency of CD83+ in PBL of BD mice (I). The frequency of regulatory T cells was analyzed by FACS in normal control, BDN, BD and BD mice treated with E. rectale (J-P). The frequencies of NK1.1+, CD4+, CD8+ and CD11b+ cells in normal, E. rectale-treated normal, BD and $E$. rectale-treated $\mathrm{BD}$ mice were evaluated by FACS analysis $(\mathbf{Q}-\mathbf{T})$. Administration of $E$. rectale $(1.7 \times 108)$ for 10 consecutive days significantly reduced the severity score (U) and improved symptoms $(\mathbf{V})$ in BD mice. Experiments were performed independently at least three times. The $p$-value was determined by the Kruskal-Wallis test. 

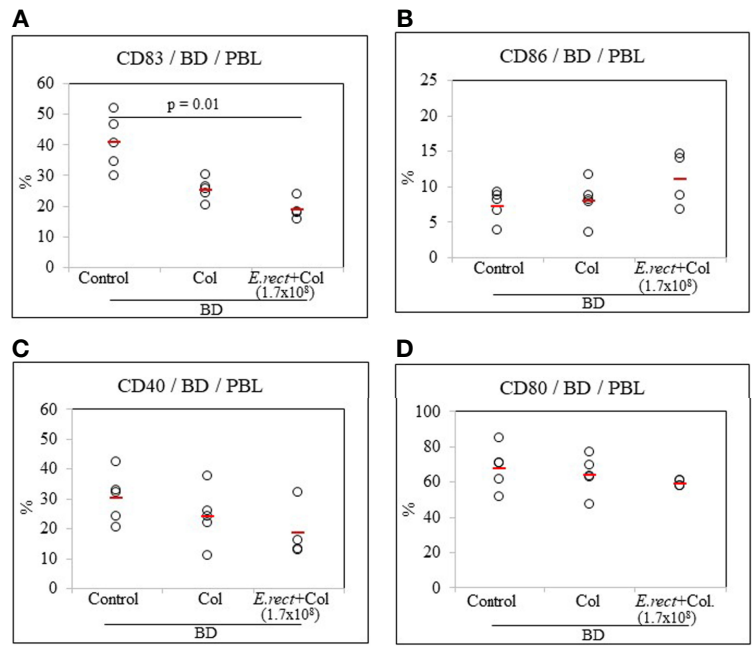

D

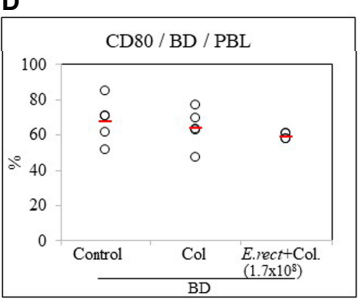

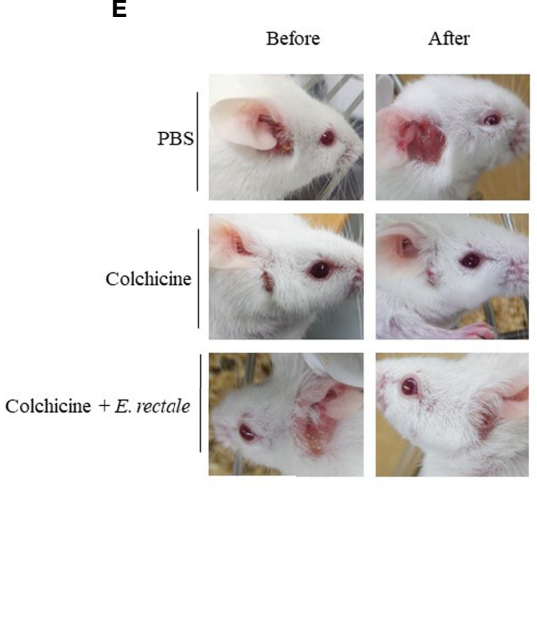

FIGURE 7 | The frequency of DC activation markers in BD mice after the administration of colchicine alone or in combination with $E$. rectale. The frequency of CD83, CD86, CD40, and CD80 on the surface of PBL of BD mice was evaluated by FACS analysis (A-D). Changes in symptoms after treatment (E). The p-value was determined by the Kruskal-Wallis test.

colchicine alone or in combination with E. rectale to $\mathrm{BD}$ mice, Treg cells were not upregulated in PBL (Supplementary Figure S2). The frequencies of CD4+, CD8+, CD11b+, and CD11c+ cells in the $\mathrm{LN}$ of $\mathrm{BD}$ mice treated with colchicine alone or in combination with $E$. rectale were not significant among the groups (Supplementary Figure S3).
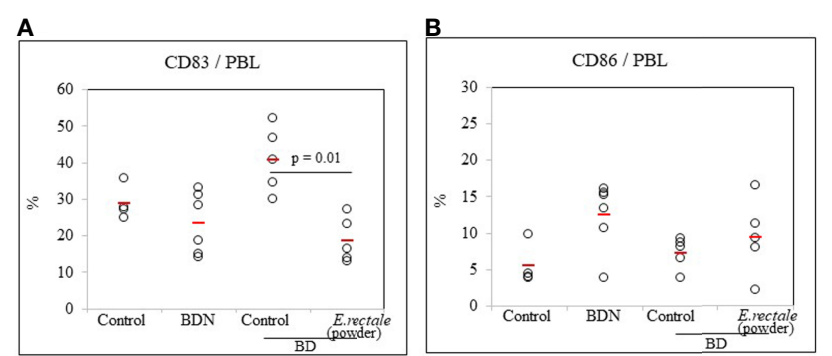

C

D
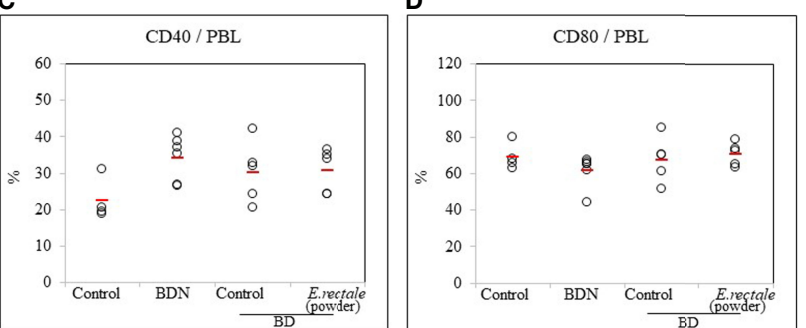

FIGURE 8 | FACS analysis of the frequency of DC activation markers in BD mice after administration of lyophilized $E$. rectale (A-D). The p-value was determined by the Kruskal-Wallis test. The experiments were performed more than three independent times.

\section{Lyophilized Eubacterium rectale Reduces the Frequency of CD83+ Cells in BD Mice}

Whether $E$. rectale in the form of freeze-dried powder could regulate $\mathrm{CD} 83+$ cells in $\mathrm{BD}$ mice was investigated. As a result of the oral administration of $0.5 \mathrm{mg}$ of freeze-dried E. rectale to $\mathrm{BD}$ mice (once daily, 10 consecutive days), the frequency of CD83+ cells in BD mice was significantly reduced compared to untreated $\mathrm{BD}$ mice $(18.62 \pm 6.17 \%$ vs. $40.72 \pm 8.91 \%, \mathrm{p}=0.01)$ (Figure 8A). No significant differences were observed in the frequency of CD86+, CD40+, or CD80+ cells after freeze-dried E. rectale treatment (Figures 8B-D). Freeze-dried E. rectale treatment had no effect on the increase in Treg cell frequencies compared to control (Supplementary Figure S4).

\section{Eubacterium rectale Reduces Serum IL-17 Levels in BD Mice}

Several studies on BD have demonstrated that a significant increase in serum IL-17 is an indicator of relapse or infection recurrence (40, 41). To determine whether E. rectale administration could improve BD symptoms by downregulating IL-17, serum IL-17 levels were measured by ELISA in BD mice administered E. rectale. $\mathrm{BD}$ mice showed higher concentrations of IL-17 than control mice $(45.0 \pm 8.05 \mathrm{pg} / \mathrm{mL}$ vs. $8.30 \pm 9.77 \mathrm{pg} / \mathrm{mL})$, statistically it was not significant. Intraperitoneal treatment with butyrate downregulated serum IL-17 levels in BD mice compared to the untreated BD mice $(22.05 \pm 12.30 \mathrm{pg} / \mathrm{mL}$ vs. $45.0 \pm 8.05 \mathrm{pg} / \mathrm{mL})$. Serum IL-17 levels were downregulated in $E$. rectale-treated $\mathrm{BD}$ mice compared to untreated BD mice $(22.05 \pm 12.30 \mathrm{pg} / \mathrm{mL}$ vs. $45.0 \pm 8.05 \mathrm{pg} / \mathrm{mL})$ (Figure 9). However, no statistical significance was observed between the groups. 


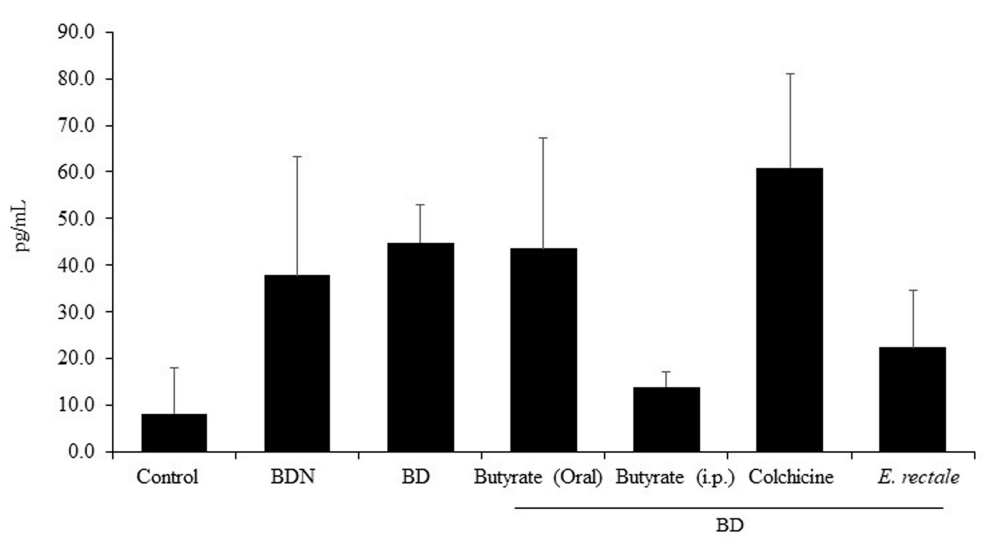

FIGURE 9 | Serum IL-17 levels in BD mice treated with butyrate orally or intraperitoneally, E. rectale, or colchicine were analyzed by ELISA. The p-value was determined by the Kruskal-Wallis test.

\section{DISCUSSION}

Recently, research on microbiota has been actively conducted. Dysbiosis, an imbalance in gut microflora, can lead to many metabolic and inflammatory pathologies, such as $\mathrm{BD}(12,27,42)$, multiple sclerosis (43), RA (44), ankylosing spondylitis (45), and inflammatory bowel disease (46). BD patients showed reduced gut microbial diversity (47). Fecal bacterial transplantation from BD patients was found to significantly exacerbate uveitis in B10RIII mice (12). This suggests that controlling the microflora may also have the potential to improve BD symptoms. Patients with active BD have low levels of butyrate-producing bacteria (12). Bacterial species exert anti-inflammatory effects by secreting several shortchain fatty acids, including butyrate, one of the major metabolites of the gut microflora (48). In vitro human monocyte-derived DCs treated with butyrate revealed a strong downregulation of CD83 (49). After confirming the association between BD inflammation and $\mathrm{CD} 83$, and the association between $\mathrm{BD}$ inflammation and gut microbiota, whether inflammation could be alleviated by regulating intestinal bacteria was investigated. In particular, E. rectale was selected as a butyrate-secreting strain because it has the advantage of inhabiting the human colon. Eubacterium was also one of the most prevalent commensals in healthy populations compared to COVID19 patients (50).

In $\mathrm{BD}$ patients with ocular symptoms, Bacteroidetes, Firmicutes, and Proteobacteria were the dominant phyla in the gut microbiota (12). In our study, BD mice showed a similar tendency. The phylum Tenericutes was higher in BD mice. Tenericutes bacteria were also highly abundantly expressed in the pathological setting of patients with Crohn's disease (51).

The families Bacteroidaceae and Prevotellaceae were significantly upregulated in $\mathrm{BD}$ mice. Bacteroidaceae and Prevotellaceae were decreased after IL-23 inhibition in SKG mice. IL-23 favors the outgrowth of spondyloarthritis-associated pathogens (52). IL-23 was the most frequently detectable cytokine in active Behçet's patients (53). Bacteroidaceae and Prevotellaceae may affect $\mathrm{BD}$ inflammation through IL-23 production. The family Peptococcaceae was found to be significantly downregulated in $\mathrm{BD}$ mice compared to normal healthy mice. Peptococcaceae bacteria were also downregulated in mice with a disrupted gut barrier induced by cyclophosphamide (54). Peptococcaceae may play a protective role in $\mathrm{BD}$ intestinal symptoms.

The genus Prevotella was significantly higher in $\mathrm{BD}$ patients (12) and BD mice. Prevotella expansion was also observed in the ileum of intestinal inflamed mice (55). Prevotella strain $P$. intermedia was one of the periopathogens with an association between periodontal pathogenicity and atheromatous plaques (56). Prevotella appears to contribute to the generation of inflammation in various diseases.

The genus Bacteroides was downregulated in BD patients (57) and $\mathrm{BD}$ mice compared to normal controls. Bacteroides strains have good and bad features (58). Strains B. caccae and B. vulgatus, showing good properties, were downregulated in $\mathrm{BD}$ mice. B. caccae plays a role in pectin fermentation and secretes acetate (59). Acetate is known to attenuate inflammasome activation (60). Increased inflammasome expression has been reported in $\mathrm{BD}$ patients with skin manifestations (61) and $\mathrm{BD}$ patients with intestinal problems (62). B. vulgatus attenuated atherosclerosis through Foxp3 upregulation and TNF $\alpha$ downregulation (63). Foxp3 has been shown to be a master regulator of Treg cell function (64), and the upregulation of Treg cells ameliorated inflammatory BD symptoms (65). TNF $\alpha$ downregulation correlated with an improvement in $\mathrm{BD}$ symptoms in mice (66) and patients (67).

The genus Butyricicoccus was downregulated in BD mice and models of inflammatory bowel disease. Butyricicoccus strain $B$. pullicaecorum was able to attenuate chemically induced colitis through the downregulation of TNF $\alpha$ (68).

CD83 is a DC activation marker and is also expressed on monocytes, B cells, NK cells, and T cells (24). DCs are a key 
initiator and are involved in innate and adaptive immunity at the forefront of the immune response (69). In an inflammatory environment, autoreactive $\mathrm{T}$ cells are initially activated by DCs and activated T cells secrete TNF and IL-17, which recruit macrophages and other inflammatory cytokines $(18,70)$. Activated DCs in humans and mice highly and stably express CD83 (25). The inhibition of CD83 improved BD symptoms in mice (26). This suggests that CD83 may play an important role in regulating the inflammatory response in $\mathrm{BD}$. In this study, it was found that the frequency of CD83+ cells was higher in $\mathrm{BD}$ patients with arthritis than in healthy controls. Consistent with expression in the patients, there was also a higher frequency of CD83+ cells in BD mice. Therefore, CD83 inhibition through regulation of the gut microbiota could be a target for inflammation management. Butyrate treatment downregulated CD83+ cell frequency and upregulated CD86+ cell frequency. Abatacept, a modulator of the CD80/CD86-CD28 signal for T cell activation, also downregulated CD83+ cell frequency and upregulated CD86+ cell frequency, with a trend similar to that of butyrate. Butyrate and Abatacept treatment-induced improvement did not affect the Treg cell population (26), whereas, E. rectale treatment downregulated only CD83+ cells, not CD86+ cells. According to P. Yang, CD86 expression decreased after treatment with 5-Aza-2'-deoxycytidine, a DNA demethylating drug, for ocular symptoms in BD patients. CD83 expression was not altered by this treatment (71).

Colchicine is an effective medicine frequently prescribed for $\mathrm{BD}$ patients $(72,73)$. Colchicine alone or in combination with rebamipide improved $\mathrm{BD}$ symptoms in mice $(2,74)$. In this study, the combination of colchicine and E. rectale significantly reduced the frequency of $\mathrm{CD} 83+$ cells compared to colchicine alone. Colchicine treatment was not able to significantly increase the proportion of Foxp3+ Treg cells in BD patients (75). Similarly, colchicine alone or in combination with $E$. rectale did not modulate the frequency of Treg cells in BD mice. Taken together, it was confirmed that $\mathrm{BD}$ symptoms could be improved by regulating the expression of $\mathrm{DC}$ activation-related markers. $\mathrm{BD}$ has widespread symptoms and affects many organs, including the mouth, skin, genitals, eyes, intestines, and joints (76). More research is needed on whether antigen-presenting cell activation markers change differently depending upon the symptoms, composition of the symptoms, and the treatment of BD.

Lyophilization is a process for improving the stability of a product in the form of a dry powder without losing the characteristics of the product. The process involves removing moisture from the product in a vacuum at a sufficiently low temperature $(77,78)$. Freeze-dried storage of bacterial strains provides ease of use. The oral administration of E. rectale lyophilized powder showed a similar downregulation of CD83, and this form can be applied to human applications.

In this study, we found that increased levels of CD83+ cells were associated with disease symptoms in both BD patients and $\mathrm{BD}$ mice. Changes in the composition of the intestinal microbiota using the colon-resident bacterial strain $E$. rectale showed a therapeutic effect in $\mathrm{BD}$ mice, accompanied by modulation of the DC activation marker phenotype. Thus, $E$. rectale is expected to be applied to patients with systemic inflammatory $\mathrm{BD}$ in the future.

\section{DATA AVAILABILITY STATEMENT}

The16S rRNA metagenomic data has been deposited in NCBI under the accession number PRJNA723404.

\section{ETHICS STATEMENT}

The studies involving human participants were reviewed and approved by Institutional Review Board of Ajou University Hospital (approval number: AJIRB-BMR-SMP13-398). The patients/participants provided their written informed consent to participate in this study. The animal study was reviewed and approved by Institutional Animal Care and Use Committee of Ajou University (approval number: AMC-2018-0017).

\section{AUTHOR CONTRIBUTIONS}

SS contributed to the concept and design of the study as well as data analysis and interpretation. SMSI, HOB, and HMR participated in data acquisition, analysis, and interpretation. SI and HS cared for the animals. JYJ, HAK, and CHS provided human samples. SS and SMSI wrote the manuscript. All authors contributed to the article and approved the submitted version.

\section{FUNDING}

This research was supported by a grant (2017R1D1A1B03032168) from the Basic Science Research Program through the National Research Foundation of Korea (NRF) funded by the Ministry of Education, Science, and Technology. It was also supported by an NRF grant funded by the Korean government (MIST) (2020R1A2C2012721) and the Korea Health Technology R\&D Project through the Korea Health Industry Development Institute, funded by the Ministry of Health \& Welfare, Republic of Korea (HI16C0992).

\section{SUPPLEMENTARY MATERIAL}

The Supplementary Material for this article can be found online at: https://www.frontiersin.org/articles/10.3389/fimmu.2021. 712312/full\#supplementary-material

Supplementary Figure 1 | The frequency of CD4+, CD8+, CD11b+, and CD11C+ cells in lymph node ( $\mathrm{LN})$ cells of $\mathrm{BD}$ mice treated orally and intraperitoneally with butyrate was assessed by FACS analysis (A-D). The p-value was determined by the KruskalWallis test. The experiments were performed independently at least three times. 
Supplementary Figure 2 | The frequency of regulatory T cells in BD mice treated with colchicine or the combination of colchicine and $E$. rectale was analyzed by FACS (A-G). Untreated BD mice were used as the control group. The p-value was determined by the Kruskal-Wallis test. The experiments were performed independently at least three times.

Supplementary Figure 3 | The frequency of $C D 4+, C D 8+, C D 11 b+$, and $\mathrm{CD} 11 \mathrm{c}+$ cells in $\mathrm{LN}$ of $\mathrm{BD}$ mice treated with colchicine or the combination of

\section{REFERENCES}

1. Tong B, Liu X, Xiao J, Su G. Immunopathogenesis of Behcet's Disease. Front Immunol (2019) 10:665. doi: 10.3389/fimmu.2019.00665

2. Islam SMS, Sohn S. HSV-Induced Systemic Inflammation as an Animal Model for Behcet's Disease and Therapeutic Applications. Viruses (2018) 10 (9):511-24. doi: 10.3390/v10090511

3. Sezer FN. The Isolation of a Virus as the Cause of Behcet's Diseases. Am J Ophthalmol (1953) 36(3):301-15. doi: 10.1016/0002-9394(53)91372-5

4. Studd M, McCance DJ, Lehner T. Detection of HSV-1 DNA in Patients With Behcet's Syndrome and in Patients With Recurrent Oral Ulcers by the Polymerase Chain Reaction. J Med Microbiol (1991) 34(1):39-43. doi: 10.1099/00222615-34-1-39

5. Lee S, Bang D, Cho YH, Lee ES, Sohn S. Polymerase Chain Reaction Reveals Herpes Simplex Virus DNA in Saliva of Patients With Behcet's Disease. Arch Dermatol Res (1996) 288(4):179-83. doi: 10.1007/BF02505221

6. Tojo M, Zheng X, Yanagihori H, Oyama N, Takahashi K, Nakamura K, et al. Detection of Herpes Virus Genomes in Skin Lesions From Patients With Behçet's Disease and Other Related Inflammatory Diseases. Acta Derm Venereol (2003) 83(2):124-7. doi: 10.1080/00015550310007472

7. O'Hara AM, Shanahan F. The Gut Flora as a Forgotten Organ. EMBO Rep (2006) 7(7):688-93. doi: 10.1038/sj.embor.7400731

8. Opazo MC, Ortega-Rocha EM, Coronado-Arrázola I, Bonifaz LC, Boudin H, Neunlist M, et al. Intestinal Microbiota Influences Non-Intestinal Related Autoimmune Diseases. Front Microbiol (2018) 9:432. doi: 10.3389/ fmicb.2018.00432

9. Marchesi J, Shanahan F. The Normal Intestinal Microbiota. Curr Opin Infect Dis (2007) 20(5):508-13. doi: 10.1097/QCO.0b013e3282a56a99

10. Xu H, Liu M, Cao J, Li X, Fan D, Xia Y, et al. The Dynamic Interplay Between the Gut Microbiota and Autoimmune Diseases. J Immunol Res (2019) 2019:7546047. doi: 10.1155/2019/7546047

11. Ilhan F, Demir T, Turkcuoglu P, Turgut B, Demir N, Godekmerdan A. Th1 Polarization of the Immune Response in Uveitis in Behcet's Disease. Can J Ophthalmol (2008) 43(1):105-8. doi: 10.3129/107-179

12. Ye Z, Zhang N, Wu C, Zhang X, Wang Q, Huang X, et al. A Metagenomic Study of the Gut Microbiome in Behcet's Disease. Microbiome (2018) 6 (1):135. doi: 10.1186/s40168-018-0520-6

13. Sohn S, Lee ES, Bang D, Lee S. Behçet's Disease-Like Symptoms Induced by the Herpes Simplex Virus in ICR Mice. Eur J Dermatol (1998) 8(1):21-3.

14. Nanke Y, Yago T, Kotake S. The Role of Th17 Cells in the Pathogenesis of Behcet's Disease. J Clin Med (2017) 6(7):74-81. doi: 10.3390/jcm6070074

15. Pineton de Chambrun M, Wechsler B, Geri G, Cacoub P, Saadoun D. New Insights Into the Pathogenesis of Behcet's Disease. Autoimmun Rev (2012) 11 (10):687-98. doi: 10.1016/j.autrev.2011.11.026

16. Deuter CM, Kotter I, Wallace GR, Murray PI, Stubiger N, Zierhut M. Behcet's Disease: Ocular Effects and Treatment. Prog Retin Eye Res (2008) 27(1):11136. doi: 10.1016/j.preteyeres.2007.09.002

17. Sohn S, Lee ES, Bang D. Learning From HSV-Infected Mice as a Model of Behcet's Disease. Clin Exp Rheumatol (2012) 30(3 Suppl 72):S96-103.

18. Tai Y, Wang Q, Korner H, Zhang L, Wei W. Molecular Mechanisms of T Cells Activation by Dendritic Cells in Autoimmune Diseases. Front Pharmacol (2018) 9:642. doi: 10.3389/fphar.2018.00642

19. Hodge JW, Rad AN, Grosenbach DW, Sabzevari H, Yafal AG, Gritz L, et al. Enhanced Activation of $\mathrm{T}$ Cells by Dendritic Cells Engineered to Hyperexpress a Triad of Costimulatory Molecules. J Natl Cancer Inst (2000) 92(15):1228-39. doi: 10.1093/jnci/92.15.1228

20. Sharpe AH. Mechanisms of Costimulation. Immunol Rev (2009) 229(1):5-11. doi: 10.1111/j.1600-065X.2009.00784.X colchicine and $E$. rectale was analyzed by FACS (A-D). Untreated BD mice were used as the control group. The $p$-value was determined by the Kruskal-Wallis test. The experiments were performed independently at least three times.

Supplementary Figure 4 | The frequency of regulatory T cells in BD mice treated with $E$. rectale in culture solution or lyophilized $E$. rectale powder was analyzed by FACS (A-G). The p-value was determined by the Kruskal-Wallis test. The experiments were performed independently at least three times.

21. Aerts-Toegaert C, Heirman C, Tuyaerts S, Corthals J, Aerts JL, Bonehill A, et al. CD83 Expression on Dendritic Cells and T Cells: Correlation With Effective Immune Responses. Eur J Immunol (2007) 37(3):686-95. doi: 10.1002/eji.200636535

22. Kawamura K, Iyonaga K, Ichiyasu H, Nagano J, Suga M, Sasaki Y. Differentiation, Maturation, and Survival of Dendritic Cells by Osteopontin Regulation. Clin Diagn Lab Immunol (2005) 12(1):206-12. doi: 10.1128/ cdli.12.1.206-212.2005

23. Berchtold S, Muhl-Zurbes P, Heufler C, Winklehner P, Schuler G, Steinkasserer A. Cloning, Recombinant Expression and Biochemical Characterization of the Murine CD83 Molecule Which Is Specifically Upregulated During Dendritic Cell Maturation. FEBS Lett (1999) 461 (3):211-6. doi: 10.1016/S0014-5793(99)01465-9

24. Ju X, Silveira PA, Hsu W-H, Elgundi Z, Alingcastre R, Verma ND, et al. The Analysis of CD83 Expression on Human Immune Cells Identifies a Unique CD83+-Activated T Cell Population. J Immunol (2016) 197(12):4613-25. doi: $10.4049 /$ jimmunol.1600339

25. Li Z, Ju X, Silveira PA, Abadir E, Hsu W-H, Hart DNJ, et al. CD83: Activation Marker for Antigen Presenting Cells and Its Therapeutic Potential. Front Immunol (2019) 10:1312(1312):1312-20. doi: 10.3389/fimmu.2019.01312

26. Islam SMS, Byun HO, Choi B, Sohn S. Inhibition of CD83 Alleviates Systemic Inflammation in Herpes Simplex Virus Type 1-Induced Behçet's Disease Model Mouse. Mediators Inflammation (2019) 2019:5761392. doi: 10.1155/ $2019 / 5761392$

27. Consolandi C, Turroni S, Emmi G, Severgnini M, Fiori J, Peano C, et al. Behçet's Syndrome Patients Exhibit Specific Microbiome Signature. Autoimmun Rev (2015) 14(4):269-76. doi: 10.1016/j.autrev.2014.11.009

28. Rivière A, Selak M, Lantin D, Leroy F, De Vuyst L. Bifidobacteria and Butyrate-Producing Colon Bacteria: Importance and Strategies for Their Stimulation in the Human Gut. Front Microbiol (2016) 7:979. doi: 10.3389/ fmicb.2016.00979

29. Gevers D, Kugathasan S, Denson LA, Vázquez-Baeza Y, Van Treuren W, Ren B, et al. The Treatment-Naive Microbiome in New-Onset Crohn's Disease. Cell Host Microbe (2014) 15(3):382-92. doi: 10.1016/j.chom.2014.02.005

30. Takahashi K, Nishida A, Fujimoto T, Fujii M, Shioya M, Imaeda H, et al. Reduced Abundance of Butyrate-Producing Bacteria Species in the Fecal Microbial Community in Crohn's Disease. Digestion (2016) 93(1):59-65. doi: $10.1159 / 000441768$

31. Vaahtovuo J, Munukka E, Korkeamäki M, Luukkainen R, Toivanen P. Fecal Microbiota in Early Rheumatoid Arthritis. J Rheumatol (2008) 35(8):1500-5.

32. Vermeiren J, Van den Abbeele P, Laukens D, Vigsnaes LK, De Vos M, Boon $\mathrm{N}$, et al. Decreased Colonization of Fecal Clostridium Coccoides/Eubacterium Rectale Species From Ulcerative Colitis Patients in an In Vitro Dynamic Gut Model With Mucin Environment. FEMS Microbiol Ecol (2012) 79(3):685-96. doi: 10.1111/j.1574-6941.2011.01252.x

33. Yun SJ, Kim K, Lee E-S, Park S. The Suppressive Effect of Butyrate and Bromopyruvate on Inflammatory Cytokine Production and Short Chain Fatty Acid Receptor Expression by Blood Mononuclear Cells in Patients With Behçet's Disease. Ann Dermatol (2018) 30(5):566-74. doi: 10.5021/ad.2018.30.5.566

34. Choi B, Kim HA, Suh CH, Byun HO, Jung JY, Sohn S. The Relevance of miRNA-21 in HSV-Induced Inflammation in a Mouse Model. Int J Mol Sci (2015) 16(4):7413-27. doi: 10.3390/ijms16047413

35. Shoaie S, Karlsson F, Mardinoglu A, Nookaew I, Bordel S, Nielsen J. Understanding the Interactions Between Bacteria in the Human Gut Through Metabolic Modeling. Sci Rep (2013) 3:2532. doi: 10.1038/srep02532

36. Arora T, Bäckhed F. The Gut Microbiota and Metabolic Disease: Current Understanding and Future Perspectives. J Intern Med (2016) 280(4):339-49. doi: $10.1111 /$ joim. 12508 
37. International Study Group for Behçet's D. Criteria for Diagnosis of Behcet's Disease. Lancet (1990) 335(8697):1078-80. doi: 10.1016/0140-6736(90)92643-V

38. Aktulga E, Altac M, Muftuoglu A, Ozyazgan Y, Pazarli H, Tuzun Y, et al. A Double Blind Study of Colchicine in Behcet's Disease. Haematologica (1980) 65(3):399-402. doi: 10.1002/1529-0131

39. Bang D. Treatment of Behcet's Disease. Yonsei Med J (1997) 38(6):401-10. doi: 10.3349/ymj.1997.38.6.401

40. Shen H, Xia LP, Lu J. Elevated Levels of Interleukin-27 and Effect on Production of Interferon-Gamma and Interleukin-17 in Patients With Behcet's Disease. Scand J Rheumatol (2013) 42(1):48-51. doi: 10.3109/ 03009742.2012.704391

41. Ahmadi M, Yousefi M, Abbaspour-Aghdam S, Dolati S, Aghebati-Maleki L, Eghbal-Fard S, et al. Disturbed Th17/Treg Balance, Cytokines, and miRNAs in Peripheral Blood of Patients With Behcet's Disease. J Cell Physiol (2019) 234 (4):3985-94. doi: 10.1002/jcp.27207

42. Seoudi N, Bergmeier LA, Drobniewski F, Paster B, Fortune F. The Oral Mucosal and Salivary Microbial Community of Behcet's Syndrome and Recurrent Aphthous Stomatitis. J Oral Microbiol (2015) 7:27150. doi: $10.3402 /$ jom.v7.27150

43. Berer K, Gerdes LA, Cekanaviciute E, Jia X, Xiao L, Xia Z, et al. Gut Microbiota From Multiple Sclerosis Patients Enables Spontaneous Autoimmune Encephalomyelitis in Mice. Proc Natl Acad Sci USA (2017) 114(40):10719-24. doi: 10.1073/pnas.1711233114

44. Zhang X, Zhang D, Jia H, Feng Q, Wang D, Liang D, et al. The Oral and Gut Microbiomes Are Perturbed in Rheumatoid Arthritis and Partly Normalized After Treatment. Nat Med (2015) 21(8):895-905. doi: 10.1038/nm.3914

45. Wen C, Zheng Z, Shao T, Liu L, Xie Z, Le Chatelier E, et al. Quantitative Metagenomics Reveals Unique Gut Microbiome Biomarkers in Ankylosing Spondylitis. Genome Biol (2017) 18(1):142. doi: 10.1186/s13059-017-1271-6

46. Morgan XC, Tickle TL, Sokol H, Gevers D, Devaney KL, Ward DV, et al. Dysfunction of the Intestinal Microbiome in Inflammatory Bowel Disease and Treatment. Genome Biol (2012) 13(9):R79. doi: 10.1186/gb-2012-13-9-r79

47. van der Houwen TB, van Laar JAM, Kappen JH, van Hagen PM, de Zoete MR, van Muijlwijk GH, et al. Behçet's Disease Under Microbiotic Surveillance? A Combined Analysis of Two Cohorts of Behçet's Disease Patients. Front Immunol (1192) 2020:1192. doi: 10.3389/fimmu.2020.01192

48. Park J, Kim M, Kang SG, Jannasch AH, Cooper B, Patterson J, et al. ShortChain Fatty Acids Induce Both Effector and Regulatory T Cells by Suppression of Histone Deacetylases and Regulation of the mTOR-S6K Pathway. Mucosal Immunol (2015) 8(1):80-93. doi: 10.1038/mi.2014.44

49. Millard AL, Mertes PM, Ittelet D, Villard F, Jeannesson P, Bernard J. Butyrate Affects Differentiation, Maturation and Function of Human MonocyteDerived Dendritic Cells and Macrophages. Clin Exp Immunol (2002) 130 (2):245-55. doi: 10.1046/j.0009-9104.2002.01977.x

50. Gautier T, David-Le Gall S, Sweidan A, Tamanai-Shacoori Z, Jolivet-Gougeon A, Loreal O, et al. Next-Generation Probiotics and Their Metabolites in COVID-19. Microorganisms (2021) 9(5):941. doi: 10.3390/microorganisms 9050941

51. Russo E, Giudici F, Ricci F, Scaringi S, Nannini G, Ficari F, et al. Diving Into Inflammation: A Pilot Study Exploring the Dynamics of the ImmuneMicrobiota Axis in Ileal Tissue Layers of Patients With Crohn's Disease. J Crohns Colitis (2021). doi: 10.1093/ecco-jcc/jjab034

52. Rehaume LM, Matigian N, Mehdi AM, Lachner N, Bowerman KL, Daly J, et al. IL-23 Favours Outgrowth of Spondyloarthritis-Associated Pathobionts and Suppresses Host Support for Homeostatic Microbiota. Ann Rheum Dis (2019) 78(4):494-503. doi: 10.1136/annrheumdis-2018-214381

53. Sonmez C, Yucel AA, Yesil TH, Kucuk H, Sezgin B, Mercan R, et al. Correlation Between IL-17a/F, IL-23, IL-35 and IL-12/-23 (P40) Levels in Peripheral Blood Lymphocyte Cultures and Disease Activity in Behcet's Patients. Clin Rheumatol (2018) 37(10):2797-804. doi: 10.1007/s10067-0184049-7

54. Zhou R, He D, Xie J, Zhou Q, Zeng H, Li H, et al. The Synergistic Effects of Polysaccharides and Ginsenosides From American Ginseng (Panax Quinquefolius L.) Ameliorating Cyclophosphamide-Induced Intestinal Immune Disorders and Gut Barrier Dysfunctions Based on MicrobiomeMetabolomics Analysis. Front Immunol (2021) 12:665901(1273). doi: 10.3389/fimmu.2021.665901

55. Dobranowski PA, Tang C, Sauvé JP, Menzies SC, Sly LM. Compositional Changes to the Ileal Microbiome Precede the Onset of Spontaneous Ileitis in
SHIP Deficient Mice. Gut Microbes (2019) 10(5):578-98. doi: 10.1080/ 19490976.2018.1560767

56. Pavlic V, Peric D, Kalezic IS, Madi M, Bhat SG, Brkic Z, et al. Identification of Periopathogens in Atheromatous Plaques Obtained From Carotid and Coronary Arteries. BioMed Res Int (2021) 2021:9986375. doi: 10.1155/2021/ 9986375

57. Yasar Bilge NS, Pérez Brocal V, Kasifoglu T, Bilge U, Kasifoglu N, Moya A, et al. Intestinal Microbiota Composition of Patients With Behçet's Disease: Differences Between Eye, Mucocutaneous and Vascular Involvement. The Rheuma-BIOTA Study. Clin Exp Rheumatol (2020) 38 Suppl 127(5):60-8.

58. Wexler HM. Bacteroides: The Good, the Bad, and the Nitty-Gritty. Clin Microbiol Rev (2007) 20(4):593-621. doi: 10.1128/cmr.00008-07

59. Sirotek K, Slováková L, Kopecný J, Marounek M. Fermentation of Pectin and Glucose, and Activity of Pectin-Degrading Enzymes in the Rabbit Caecal Bacterium Bacteroides Caccae. Lett Appl Microbiol (2004) 38(4):327-32. doi: 10.1111/j.1472-765x.2004.01492.x

60. Xu M, Jiang Z, Wang C, Li N, Bo L, Zha Y, et al. Acetate Attenuates Inflammasome Activation Through GPR43-Mediated $\mathrm{Ca}(2+)$-Dependent NLRP3 Ubiquitination. Exp Mol Med (2019) 51(7):1-13. doi: 10.1038/ s12276-019-0276-5

61. Kim EH, Park MJ, Park S, Lee ES. Increased Expression of the NLRP3 Inflammasome Components in Patients With Behçet's Disease. J Inflammation (Lond) (2015) 12:41. doi: 10.1186/s12950-015-0086-Z

62. Lee HJ, Kim JH, Hong S, Hwang I, Park SJ, Kim TI, et al. Proteomics-Based Functional Studies Reveal That Galectin-3 Plays a Protective Role in the Pathogenesis of Intestinal Behçet's Disease. Sci Rep (2019) 9(1):11716. doi: 10.1038/s41598-019-48291-1

63. Yoshida N, Emoto T, Yamashita T, Watanabe H, Hayashi T, Tabata T, et al. Bacteroides Vulgatus and Bacteroides Dorei Reduce Gut Microbial Lipopolysaccharide Production and Inhibit Atherosclerosis. Circulation (2018) 138(22):2486-98. doi: 10.1161/circulationaha.118.033714

64. Marson A, Kretschmer K, Frampton GM, Jacobsen ES, Polansky JK, MacIsaac KD, et al. Foxp3 Occupancy and Regulation of Key Target Genes During TCell Stimulation. Nature (2007) 445(7130):931-5. doi: 10.1038/nature05478

65. Shim J, Lee ES, Park S, Bang D, Sohn S. CD4(+) CD25(+) Regulatory T Cells Ameliorate Behcet's Disease-Like Symptoms in a Mouse Model. Cytotherapy (2011) 13(7):835-47. doi: 10.3109/14653249.2011.571245

66. Choi B, Kim J, Lee ES, Bang D, Sohn S. Synthesized Pyridine Compound Derivatives Decreased TNF Alpha and Adhesion Molecules and Ameliorated HSV-Induced Inflammation in a Mouse Model. Eur J Pharmacol (2011) 657 (1-3):167-72. doi: 10.1016/j.ejphar.2011.01.062

67. Alibaz-Öner F, Direskeneli H. Biologic Treatments in Behçet's Disease. Eur J Rheumatol (2021). doi: 10.5152/eurjrheum.2020.20138

68. Geirnaert A, Calatayud M, Grootaert C, Laukens D, Devriese S, Smagghe G, et al. Butyrate-Producing Bacteria Supplemented In Vitro to Crohn's Disease Patient Microbiota Increased Butyrate Production and Enhanced Intestinal Epithelial Barrier Integrity. Sci Rep (2017) 7(1):11450. doi: 10.1038/s41598017-11734-8

69. Ganguly D, Haak S, Sisirak V, Reizis B. The Role of Dendritic Cells in Autoimmunity. Nat Rev Immunol (2013) 13(8):566-77. doi: 10.1038/nri3477

70. Moro-García MA, Mayo JC, Sainz RM, Alonso-Arias R. Influence of Inflammation in the Process of T Lymphocyte Differentiation: Proliferative, Metabolic, and Oxidative Changes. Front Immunol (2018) 9:339(339): 339356. doi: 10.3389/fimmu.2018.00339

71. Qiu Y, Zhu Y, Yu H, Yi S, Su W, Cao Q, et al. Ocular Behcet's Disease Is Associated With Aberrant Methylation of Interferon Regulatory Factor 8 (IRF8) in Monocyte-Derived Dendritic Cells. Oncotarget (2017) 8(31):5127787. doi: 10.18632/oncotarget.17235

72. Yurdakul S, Mat C, Tuzun Y, Ozyazgan Y, Hamuryudan V, Uysal O, et al. A Double-Blind Trial of Colchicine in Behcet's Syndrome. Arthritis Rheum (2001) 44(11):2686-92. doi: 10.1002/1529-0131(200111)44:11<2686::aidart448>3.0.co;2-h

73. Saleh Z, Arayssi T. Update on the Therapy of Behçet Disease. Ther Adv Chronic Dis (2014) 5(3):112-34. doi: 10.1177/2040622314523062

74. Bang D, Choi B, Kwon HJ, Lee ES, Lee S, Sohn S. Rebamipide Affects the Efficiency of Colchicine for the Herpes Simplex Virus-Induced Inflammation in a Behcet's Disease Mouse Model. Eur J Pharmacol (2008) 598(1-3):112-7. doi: 10.1016/j.ejphar.2008.09.005 
75. Sugita S, Yamada Y, Kaneko S, Horie S, Mochizuki M. Induction of Regulatory T Cells by Infliximab in Behçet's Disease. Invest Ophthalmol Vis Sci (2011) 52 (1):476-84. doi: 10.1167/iovs.10-5916

76. Cheon JH. Advances in Management of Intestinal Behçet's Disease: A Perspective From Gastroenterologists. J Rheum Dis (2021) 28(1):4-16. doi: 10.4078/jrd.2021.28.1.4

77. Lyophilization of Parenteral (7/93). US Food and Drug Administration (2014).

78. Kawasaki H, Shimanouchi T, Kimura Y. Recent Development of Optimization of Lyophilization Process. J Chem (2019) 2019:14. doi: 10.1155/2019/9502856

Conflict of Interest: The authors declare that the research was conducted in the absence of any commercial or financial relationships that could be construed as a potential conflict of interest.
Publisher's Note: All claims expressed in this article are solely those of the authors and do not necessarily represent those of their affiliated organizations, or those of the publisher, the editors and the reviewers. Any product that may be evaluated in this article, or claim that may be made by its manufacturer, is not guaranteed or endorsed by the publisher.

Copyright (C) 2021 Islam, Ryu, Sayeed, Byun, Jung, Kim, Suh and Sohn. This is an open-access article distributed under the terms of the Creative Commons Attribution License (CC BY). The use, distribution or reproduction in other forums is permitted, provided the original author(s) and the copyright owner(s) are credited and that the original publication in this journal is cited, in accordance with accepted academic practice. No use, distribution or reproduction is permitted which does not comply with these terms. 